\title{
MATCHING STUDENTS TO SCHOOLS
}

\author{
Dejan Trifunovic* \\ Faculty of Economics, University of Belgrade, Belgrade, The Republic of Serbia
}

In this paper, we present the problem of matching students to schools by using different matching mechanisms. This market is specific since public schools are free and the price mechanism cannot be used to determine the optimal allocation of children in schools. Therefore, it is necessary to use different matching algorithms that mimic the market mechanism and enable us to determine the core of the cooperative game. In this paper, we will determine that it is possible to apply cooperative game theory in matching problems. This review paper is based on illustrative examples aiming to compare matching algorithms in terms of the incentive compatibility, stability and efficiency of the matching. In this paper we will present some specific problems that may occur in matching, such as improving the quality of schools, favoring minority students, the limited length of the list of preferences and generating strict priorities from weak priorities.

Keywords: matching, Boston algorithm, deferred acceptance algorithm, top trading cycles

\section{JEL Classification: C78}

\section{INTRODUCTION}

The most important role of market prices is to determine the optimal allocation of resources. However, there are certain situations where the price mechanism cannot be applied, but it is still necessary to optimally allocate resources. One example is the enrolment of students in public high schools that are free. Therefore, it is necessary to construct an algorithm for matching students to schools that mimics the functioning of the market. The subject of this research is matching students to schools in the

* Correspondence to: D. Trifunovic, Faculty of Economics, University of Belgrade, Kamenicka 6, 11000 Belgrade, The Republic of Serbia; e-mail: dejan@ekof.bg.ac.rs absence of money transfers, while the objective of the research is to show the possibility for the practical application of matching algorithms in this market.

From the methodological point of view, matching algorithms are based on the application of cooperative game theory and the mechanism design.

The basic division of games is that into cooperative and non-cooperative games. In non-cooperative games, the player maximizes his payoff for a given set of rules of the game (Backović \& Popović, 2012). In cooperative games, players make coalitions and the strategy is defined at the level of the coalition (Backović, Popović \& Stamenković, 2016). In cooperative games, it is necessary to determine the 
core of the game, when there is no coalition of players that can improve upon the allocation in the core.

The mechanism design is based on the assumption that players possess private information that they submit to the center of the mechanism. The mechanism should be based on the rules such that each player finds optimal to reveal his private information. This mechanism is incentive-compatible.

The first hypothesis which matching algorithms are based on is that it is possible to determine the core of the game and the allocation that would be obtained in the market mechanism with money transfers. The second hypothesis is that it is possible to create incentive-compatible matching algorithms.

This paper is a review paper that employs original examples to illustrate the existing results in a concise way.

In the selection of the matching mechanism, it is necessary to take into account the fact that students have an incentive to express their true preferences and that matching is stable and efficient.

A. Roth (2015) states that the matching mechanism used in New York until 2003 was very complex. The algorithm of immediate matching was used at that time, operating as follows. Students submit a list of three schools they want to attend. On the basis of the received applications, the school enrolls students with the highest priorities, who have listed that school as the first choice. If the capacity of the school is filled in the first round, it declines other applicants. In the second round, the students who were previously rejected apply to the school which is their second best choice. Schools with empty seats enroll applicants with the highest priority up to their capacity and reject other applicants. The same procedure is applied in the third round. Given the characteristics of the algorithm, it was not necessary for students to submit their preferences for more than three schools since the likelihood of their being enrolled in a school that was their fourth best choice was negligible. The students who were not enrolled after the third round are administratively assigned in the schools where there were vacancies. This algorithm was very inefficient since almost $30 \%$ of the students were enrolled in this manner. Based on the stated preferences, it can be determined that about $80 \%$ of the students were enrolled in their first-choice schools. However, the students in this algorithm do not have an incentive to express their true preferences and the school listed as the best choice in the most cases represents a strategic choice. In other words, the school listed as the best choice represents the school in which the student estimates the probability of being admitted as the highest, and often this school was not his real first choice. A more detailed analysis of the immediate matching algorithm is given in: A. Abdulkardiroglu, A. Pathak and A. Roth (2005; 2009); A. Abdulkardiroglu, A. Pathak, A. Roth and T. Sonmez (2005). Given all these problems, Alvin Roth and his colleagues have proposed the application of the deferred acceptance algorithm, which performs a temporary matching. For the application of this algorithm, A. Roth was awarded the Nobel Prize in economics in 2012, together with L. Shapely.

The deferred acceptance algorithm was first considered by D. Gale and L. Shapely (1962). Specifying the list of preferences in the deferred acceptance algorithm is much simpler. The student does not have to consider in which school there is the highest probability for him to enroll because he will not lose a priority in the school against the other students with a lower priority, as is the case in the immediate matching algorithm. Thus, the student submits his true preferences in this algorithm. This mechanism leads to a stable matching, which means that it is not possible to find a school and a student not paired with each other and that prefer each other to the pair assigned to them in the algorithm. In other words, in a stable allocation, there is no justified envy. This algorithm has proven to be significantly more successful than the immediate matching algorithm and the number of the administratively enrolled students in New York fell by ten times. At the same time, there were more students enrolled in their first choice schools, as well as more students enrolled in their second choice schools, and so on. The deferred acceptance algorithm was selected although the top trading cycle introduced by D. Gale and H. Scarf (1974) was also considered. In this mechanism, students also submit their true preferences. 
School priorities are determined based on the distance of the student's residence from the school and on the basis of whether a student has a sibling already attending that school. The students who live closer to the school have a higher priority, which is also the case with the students whose siblings have already been enrolled in that school. Priorities can be determined exogenously, when they are submitted to schools by an administrative entity, which is the case in Boston. In this case, there is a one-sided matching because students' preferences are more important than exogenously determined priorities. Another option implies that such priorities are determined by schools, which is the case in New York. In this case, priorities can also be viewed as preferences, which leads us to a two-sided matching problem. In twosided matching, schools' preferences are equally important as students' preferences, as opposed to onesided matching, where only students' preferences are relevant. When the problem of one-sided matching is concerned, no stable allocation may be Pareto optimal, unlike two-sided matching, where there is no difference between these two objectives. As far as incentive compatibility, or the true revelation of preferences, are concerned, A. Abdulkadiroğlu (2013) claims that the algorithm with this feature greatly facilitates the student's decision on submitting his preference list.

The rest of the paper is organized as follows. In the second part, the Boston matching algorithm, the deferred acceptance algorithm and the top trading cycle algorithm are presented. In the third part, a more detailed analysis of these mechanisms follows, from the point of view of incentive compatibility, stability and efficiency. The fourth part considers whether matching algorithms respect the improved ranking of the school on the preference list due to its increased quality, as well as its enrollment policy favoring minority students. In the fifth part, the properties of the matching algorithms are considered in the case of the limited length of the preference list. In the sixth part, the methods for constructing strict priorities from weak priorities are considered. The last section is reserved for the concluding remarks.

\section{MATCHING ALGHORITMS}

Matching algorithms can be illustrated by way of the following example. Suppose there are four schools $\left(c_{1^{\prime}}\right.$ $\left.c_{2}, c_{3^{\prime}}, c_{4}\right)$ with one place and four students $\left(s_{1}, s_{2}, s_{3^{\prime}}, s_{4}\right)$. The preferences and priorities are shown in Table 1 and Table 2.

Table 1 Priorities

\begin{tabular}{cccc}
\hline$\succ_{c_{1}}$ & $\succ_{C_{2}}$ & $\succ_{c_{3}}$ & $\succ_{c_{4}}$ \\
\hline$s_{4}$ & $s_{1}$ & $s_{4}$ & $s_{2}$ \\
\hline$s_{2}$ & $s_{2}$ & $s_{3}$ & $s_{3}$ \\
\hline$s_{3}$ & $s_{3}$ & $s_{2}$ & $s_{1}$ \\
\hline$s_{1}$ & $s_{4}$ & $s_{1}$ & $s_{4}$ \\
\hline
\end{tabular}

Source: Author

Table 2 Preferences

\begin{tabular}{cccc}
\hline$\succ_{\mathrm{s}_{1}}$ & $\succ_{\mathrm{S}_{2}}$ & $\succ_{\mathrm{s}_{3}}$ & $\succ_{\mathrm{s}_{4}}$ \\
\hline$c_{1}$ & $c_{4}$ & $c_{1}$ & $c_{4}$ \\
\hline$c_{2}$ & $c_{3}$ & $c_{2}$ & $c_{2}$ \\
\hline$c_{3}$ & $c_{2}$ & $c_{4}$ & $c_{1}$ \\
\hline$c_{4}$ & $c_{1}$ & $c_{3}$ & $c_{3}$ \\
\hline
\end{tabular}

Source: Author

The algorithm used in Boston is presented first, and we will see its main drawback. In the Boston algorithm, matching is immediate. Each student applies to the school that is his best choice. Schools keep students with the highest priority and reject others. In the next step, the rejected students apply to the second choice school and schools retain the students with the highest priority. The process is repeated until all students are matched to schools.

In the previous example, in the first step, Students 1 and 3 apply to School 1, whereas Students 2 and 4 apply to School 4 (Table 3). 
Table 3 Boston algorithm (1)

\begin{tabular}{cccc}
\hline$c_{1}$ & $C_{2}$ & $c_{3}$ & $C_{4}$ \\
\hline$s_{1}, S_{3}$ & & & $S_{2}, s_{4}$ \\
\hline
\end{tabular}

Source: Author

School 1 retains Student 3, who has a higher priority, while School 4 retains Student 2. In the next step, Students 1 and 4 apply to School 2 (Table 4).

Table 4 Boston algorithm (2)

\begin{tabular}{llll}
\hline$C_{1}$ & $C_{2}$ & $C_{3}$ & $C_{4}$ \\
\hline$S_{3}$ & & $S_{2}$ \\
\hline & $S_{1}, S_{4}$ & \\
\hline
\end{tabular}

Source: Author

School 2 retains Student 1, who has a higher priority. In the next step, Student 4 applies to School 1, but there are no empty seats. In the last step, this student applies to School 3, which he is paired with. Thus, in the Boston algorithm, the following matching occurs (Table 5).

Table 5 Boston algorithm (3)

\begin{tabular}{cccc}
\hline$C_{1}$ & $C_{2}$ & $C_{3}$ & $C_{4}$ \\
\hline$S_{3}$ & $S_{1}$ & $S_{4}$ & $S_{2}$ \\
\hline
\end{tabular}

Source: Author

In the deferred acceptance algorithm, students and schools are temporarily matched and the school may reject the students with whom it is temporarily matched in favor of the students with a higher priority, who apply later. In the first step, there is the same situation as in the Boston algorithm (Table 6).

Table 6 Deferred acceptance algorithm (1)

\begin{tabular}{cccc}
\hline$c_{1}$ & $c_{2}$ & $c_{3}$ & $c_{4}$ \\
\hline$s_{1} s_{3}$ & & & $s_{2}, s_{4}$ \\
\hline
\end{tabular}

Source: Author
The same situation repeats in the second step, when Students 1 and 4 apply to School 2 (Table 7).

Table 7 Deferred acceptance algorithm (2)

\begin{tabular}{cccc}
\hline$c_{1}$ & $C_{2}$ & $C_{3}$ & $C_{4}$ \\
\hline$s_{3}$ & & $s_{2}$ \\
\hline & $S_{1} s_{4}$ & \\
\hline
\end{tabular}

Source: Author

In the third step, Student 4 applies to School 1 (Table 8).

Table 8 Deferred acceptance algorithm (3)

\begin{tabular}{llll}
\hline$C_{1}$ & $C_{2}$ & $C_{3}$ & $C_{4}$ \\
\hline$S_{3}$ & & & $S_{2}$ \\
\hline & $S_{1}$ & \\
\hline$S_{4}$ & & \\
\hline
\end{tabular}

Source: Author

Now, School 1 keeps Student 4 as the best option and rejects Student 3, who applies in the next step in School 2 (Table 9).

Table 9 Deferred acceptance algorithm (4)

\begin{tabular}{llll}
\hline$C_{1}$ & $C_{2}$ & $C_{3}$ & $C_{4}$ \\
\hline & & & $S_{2}$ \\
\hline & $S_{1}$ & \\
\hline$S_{4}$ & & \\
\hline & $S_{3}$ & \\
\hline
\end{tabular}

Source: Author

School 2 retains Student 1 as the best option and in the last step, Student 3 applies to School 3, which he is paired with (Table 10). 
Table 10 Deferred acceptance algorithm (5)

\begin{tabular}{cccc}
\hline$C_{1}$ & $C_{2}$ & $C_{3}$ & $C_{4}$ \\
\hline$S_{4}$ & $S_{1}$ & $S_{3}$ & $S_{2}$ \\
\hline
\end{tabular}

Source: Author

In the top trading cycle algorithm, each student points to his first choice school and each school points to the student with the highest priority. The cycle starts with the student $i$, who points to the school $k$ that points to the student $j$, etc., wherein the last school points to the student $i$, who has actually started the cycle. The students in the cycle are matched to the schools they point to and are removed from the algorithm. The process repeats until all students have been matched.

In the first step, the situation is as follows (Figure 1):

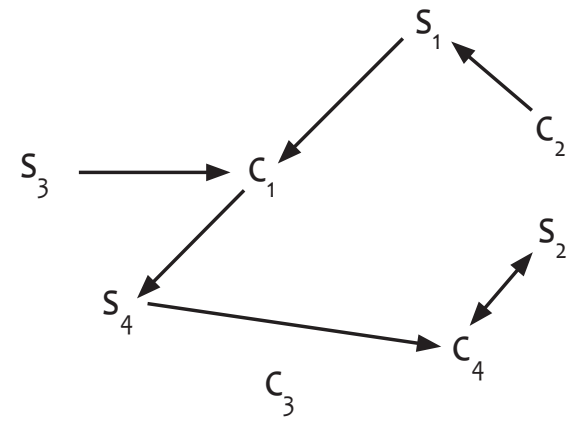

Figure 1 Top trading cycle (1)

Source: Author

Based on Figure 1, we can determine that there is a cycle consisting of School 4 and Student 2, matched and removed from the algorithm.

In the second step, the students and the schools point to their best option among the remaining schools and students (Figure 2).

Based on Figure 2, we can determine that there is a cycle consisting of $\left(s_{1}, c_{1}, s_{4}, c_{2}\right)$. Thus, Student 1 is matched to School 1, whereas Student 4 is matched to School 2. In the last step, one cycle remains and School 3 is matched to Student 3 (Figure 3).

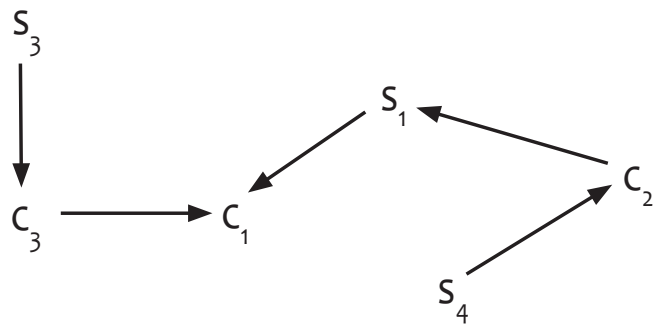

Figure 2 Top trading cycle (2)

Source: Author

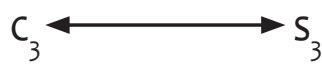

Figure 3 Top trading cycle (3)

Source: Author

Therefore, in the top trading cycle algorithm, the allocation is as follows (Table 11):

Table 11 Top trading cycle

\begin{tabular}{cccc}
\hline$C_{1}$ & $C_{2}$ & $C_{3}$ & $C_{4}$ \\
\hline$S_{1}$ & $S_{4}$ & $S_{3}$ & $S_{2}$ \\
\hline
\end{tabular}

Source: Author

If the top trading cycle allocation and the allocation in the deferred acceptance algorithm are compared to each other, we can see that in the first allocation, there is justified envy when there are the student $i$ and the school $j$, such that the student $i$ prefers the school $j$ to the school he is assigned in in the algorithm, whereas in the school $j$ the student $i$ has a higher priority than the student $l$, who is matched to the school $j$ in the algorithm. If there is justified envy, matching is not stable. Specifically, Student 3 prefers School 1, which Student 1 is enrolled in, whereas Student 3 has a higher priority in School 1 than Student 1. On the other hand, we can see that the top trading cycle allocation is more efficient than the allocation in the deferred acceptance algorithm, since Students 1 and 4 are matched to the schools that have a higher rank on their preference lists, and Students 2 and 3 are indifferent between the two allocations. 


\section{PROPERTIES OF MATCHING ALGHORITMS}

In the previous example, we have started from the assumption that the students in each algorithm express their true preferences. However, the problem with the Boston algorithm is that students have an incentive to misrepresent their preferences and the student lists the school which he estimates that he has the highest likelihood to enroll in as the best choice although it may not be his real best choice. This means that in the Boston mechanism the Nash equilibrium must be determined. This can be illustrated by the example of two students and two schools with only one place (Table 12). Suppose that the payoff is 2 if the student is enrolled in the preferred school; otherwise, his payoff is 1 .

Table 12 Preferences and priorities

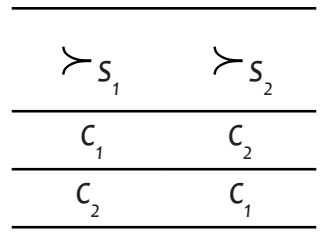

\begin{tabular}{cc}
$\succ_{c_{1}}$ & $\succ_{C_{2}}$ \\
\hline$S_{2}$ & $S_{2}$ \\
\hline$S_{1}$ & $S_{1}$ \\
\hline
\end{tabular}

Source: Author

Each student has two strategies at his disposal. The first strategy is to truthfully submit his preferences and the second is to revise the order of his actual preferences. In its normal form, this game has two Nash equilibria (Table 13).

Table 13 Nash equilibria

\begin{tabular}{lccc}
\hline & \multicolumn{3}{c}{ Student 2 } \\
\hline & & $C_{1}, C_{2}$ & $C_{2}, C_{1}$ \\
\hline \multirow{2}{*}{ Student 1 } & $C_{1}, C_{2}$ & 11 & 22 \\
\cline { 2 - 4 } & $C_{2}, C_{1}$ & 11 & 22 \\
\hline
\end{tabular}

Source: Author

In the first Nash equilibrium, both students truthfully reveal their preferences, whereas in the second Nash equilibrium, Student 1 has changed the order of his real preferences. A more detailed consideration of the Nash equilibrium in the Boston algorithm can be found in P. Pathak and T. Sönmez (2008).

The previous game that we have considered is a static game with perfect information. If players only know the probability distribution of the possible types of the other players, where the type of the player represents the order of his preferences, but do not know with certainty their preferences, the game is with imperfect information. H. Ergin and T. Sönmez (2006) argue that, in the game of imperfect information, students may be better off in the Boston algorithm than in the deferred acceptance algorithm.

In the previous discussion, we have seen that the main disadvantage of the Boston algorithm is that students do not express their true preferences. However, the Boston algorithm has some desirable properties according to F. Kojima and U. Ünver (2014). First, this algorithm strictly respects the stated order of preferences, which means that if a student is not matched to a school he prefers to the school which he is matched to, the preferred school has filled the places with the students who have listed that school in a higher place on their preference lists. Another advantage of the Boston algorithm is that an increase in the number of available places in schools may not make students worse off. The third advantage of this mechanism is that, if the number of the students who participate in matching decreases, the other students may not be in a worse position. Finally, if the student matched to a particular school is removed from the matching process, the assignment of the other students will remain the same.

The deferred acceptance algorithm leads to a true preference revelation. Another advantage of this algorithm is the elimination of justified envy, whereas the most serious drawback is that such an allocation is not efficient. In one-to-one matching, where the one side of the market makes a proposal to the other side, agents on the proposing side have an incentive to reveal their true preferences. However, the matching of students to schools is the case of manyto-one matching because schools can be matched to 
more students and each student can be matched to only one school. A. Roth (1985) has proved that, in the algorithm in which students make a proposal to schools, students reveal their true preferences. However, in the algorithm in which schools make a proposal to students, schools have an incentive to misrepresent their priorities. This can be illustrated by the following example of 3 schools and 4 students, where the first school can enroll two students and the second and third schools can only enroll one student. Suppose that the students and the schools have the following preferences and priorities (Table 14 and Table 15).

Table 14 Priorities

\begin{tabular}{ccc}
\hline$\succ_{c_{1}}$ & $\succ_{c_{2}}$ & $\succ_{c_{3}}$ \\
\hline$s_{1}$ & $s_{1}$ & $s_{3}$ \\
\hline$s_{2}$ & $s_{2}$ & $s_{1}$ \\
\hline$s_{3}$ & $s_{3}$ & $s_{2}$ \\
\hline$s_{4}$ & $s_{4}$ & $s_{4}$ \\
\hline$q_{1}=2$ & $q_{2}=1$ & $q_{3}=1$ \\
\hline
\end{tabular}

Source: Roth, 1985

Table 15 Preferences

\begin{tabular}{cccc}
\hline$\tau_{s_{1}}$ & $\tau_{s_{2}}$ & $\tau_{s_{3}}$ & $\tau_{s_{4}}$ \\
\hline$c_{3}$ & $c_{2}$ & $c_{1}$ & $c_{1}$ \\
\hline$c_{1}$ & $c_{1}$ & $c_{3}$ & $c_{2}$ \\
\hline$c_{2}$ & $c_{3}$ & $c_{2}$ & $c_{3}$ \\
\hline
\end{tabular}

Source: Roth, 1985

First, the schools are assumed to submit their true priorities. In this case, by applying the deferred acceptance algorithm, where the school makes a proposal, the following matching is obtained: $\mu^{C}=\left[\left(c_{1^{\prime}}\left(s_{3^{\prime}} s_{4}\right)\right),\left(c_{2^{\prime}}, s_{2}\right)\left(c_{3^{\prime}} s_{1}\right)\right]$. However, School 1 can be better off by misrepresenting its priorities. Suppose School 1 omits Students 1 and 3 from the list of its

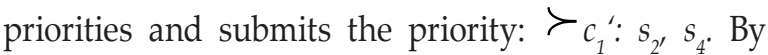
applying the deferred acceptance algorithm, in which schools make a proposal, the following matching is obtained: $\mu^{C^{\prime}}=\left[\left(c_{1^{\prime}}\left(s_{2^{\prime}}, s_{4}\right)\right),\left(c_{2^{\prime}} s_{1}\right)\left(c_{3^{\prime}} s_{3}\right)\right]$. School 1 is better off with this strategy, because it is matched to Students 2 and 4 and when it submits true priorities, it is matched to Students 3 and 4 .

In addition to the manipulation of priorities, schools can manipulate the capacity in order to be paired with a set of preferred students. The school cannot report a higher capacity than the real one is, but it can report that it has a smaller capacity. This problem has been extensively analyzed by T. Sönmez (1997).

Let us now consider the following example, in which there are 3 students and 2 schools, where School 1 can enroll two students, whereas School 2 can only enroll one student. The preferences and priorities are accounted for in Table 16 and Table 17.

Table 16 Priorities

\begin{tabular}{cc}
\hline$\succ_{c_{1}}$ & $\succ_{c_{2}}$ \\
\hline$s_{1}$ & $s_{3}$ \\
\hline$s_{2,} s_{3}$ & $s_{1}$ \\
\hline$s_{2}$ & $s_{2}$ \\
\hline$s_{3}$ & \\
\hline$q_{1}=2$ & $q_{2}=1$ \\
\hline
\end{tabular}

Source: Author

Table 17 Preferences

\begin{tabular}{ccc}
\hline$\tau_{s_{1}}$ & $\succ_{s_{2}}$ & $\succ_{s_{3}}$ \\
\hline$c_{2}$ & $c_{1}$ & $c_{1}$ \\
\hline$c_{1}$ & $c_{2}$ & $c_{2}$ \\
\hline
\end{tabular}

Source: Author 
If both schools report the true capacity, the deferred acceptance algorithm, in which students make a proposal, leads to the matching: $\mu^{S}\left(q_{1}=2, q_{2}=1\right)=\left(\left(c_{1^{\prime}}\left(s_{2^{\prime}} s_{3}\right)\right),\left(c_{2^{\prime}} s_{1}\right)\right)$.

Suppose School 1 reports that it has a lower capacity and that it can only enroll one student. After this manipulation, the deferred acceptance algorithm leads to the allocation: $\mu^{S}\left(q_{1}=1, q_{2}=1\right)=\left(\left(c_{1}, s_{1}\right),\left(c_{2^{\prime}}\right.\right.$ $\left.s_{3}\right)$ ). We can see that the school is better off with such a manipulation because it is matched to Student 1, preferred to Students 2 and 3. Somehow paradoxically, School 2 is in a better position due to the capacity manipulation by School 1 since it is now paired with Student 3, who is preferred to Student 1.

We have seen that schools have an incentive to misrepresent their priorities and capacities. However, F. Kojima and P. Pathak (2009) argue that in large markets incentives for these two types of manipulation tend to zero.

When the top trading cycle algorithm is concerned, it leads to true preference revelation and an efficient allocation. The biggest drawback of this algorithm is that it does not eliminate justified envy. A more detailed comparison of the characteristics of these two algorithms can be found in: A. Abdulkardiroğlu and T. Sönmez (2003); A. Abdulkardiroğlu (2013).

We have seen that the deferred acceptance algorithm leads to a loss of efficiency compared to the top trading cycle. Starting from this idea, O. Kesten (2010) considers whether it is possible to improve the efficiency of the deferred acceptance algorithm by changing the order of schools based on students' preferences. If we return to our initial example, in the first step of the deferred acceptance algorithm, Student 3 applies to School 1, but this does not bring any benefit to him because in the later steps of the algorithm, he was rejected at this school, whereas for Student 1, who is rejected in the first step, School 1 is the best choice. Thus, Student 3 creates negative externalities to Student 1, without any benefit for himself. This is precisely where O. Kesten (2010) sees an opportunity to improve the efficiency of the deferred acceptance algorithm, by deleting critical schools from the list of preferences of the students who create negative externalities without benefits for themselves.

For the application of this algorithm, it is necessary that the students who violate the matching of others without any benefit for themselves should accept the elimination of the critical schools from the list of their preferences. This algorithm is referred to as the Efficiency-Adjusted Deferred-Acceptance Mechanism (EADAM) and in this procedure, the loss of efficiency as a result of the previously described reason is eliminated. It is obvious that this modified algorithm Pareto-dominates the standard deferred acceptance algorithm. If all the students who create negative externalities consent to the elimination of the critical schools from the list of their preferences, the modified algorithm leads to the allocation that is Pareto-efficient.

In the previous example, School 1 should be deleted from the list of the preferences of Student 3, after which, the deferred acceptance algorithm can be applied. However, after this change, we can see that Student 3 re-creates negative externalities to the other students without any benefit for himself by applying to School 2 because he will be rejected in the next steps of the algorithm in this school. Therefore, it is necessary to delete Schools 1 and 2 from the list of preferences of Student 3. After these changes, which are presented in Table 18 and Table 19, the modified deferred acceptance algorithm can be applied.

Table 18 Priorities

\begin{tabular}{cccc}
\hline$\succ_{c_{1}}$ & $\succ_{c_{2}}$ & $\succ_{c_{3}}$ & $\succ_{c_{4}}$ \\
\hline$s_{4}$ & $s_{1}$ & $s_{4}$ & $s_{2}$ \\
\hline$s_{2}$ & $s_{2}$ & $s_{3}$ & $s_{3}$ \\
\hline$s_{3}$ & $s_{3}$ & $s_{2}$ & $s_{1}$ \\
\hline$s_{1}$ & $s_{4}$ & $s_{1}$ & $s_{4}$ \\
\hline
\end{tabular}

Source: Author 
Table 19 Preferences

\begin{tabular}{cccc}
\hline$\succ_{\mathrm{S}_{1}}$ & $\succ_{\mathrm{S}_{2}}$ & $\succ_{\mathrm{S}_{3}}$ & $\succ_{\mathrm{S}_{4}}$ \\
\hline $\mathrm{c}_{1}$ & $\mathrm{c}_{4}$ & & $\mathrm{c}_{4}$ \\
\hline $\mathrm{c}_{2}$ & $\mathrm{c}_{3}$ & & $\mathrm{c}_{2}$ \\
\hline $\mathrm{c}_{3}$ & $\mathrm{c}_{2}$ & $\mathrm{c}_{4}$ & $\mathrm{c}_{1}$ \\
\hline $\mathrm{c}_{4}$ & $\mathrm{c}_{1}$ & $\mathrm{c}_{3}$ & $\mathrm{c}_{3}$ \\
\hline
\end{tabular}

Source: Author

With these changes in the first step of the deferred acceptance algorithm, the situation (Table 20) is as follows:

Table 20 Increasing efficiency (1)

\begin{tabular}{cccc}
\hline$c_{1}$ & $c_{2}$ & $c_{3}$ & $c_{4}$ \\
\hline$s_{1}$ & & & $s_{2}, s_{3}, s_{4}$ \\
\hline
\end{tabular}

Source: Author

Students 3 and 4 are rejected in School 4 and apply to Schools 3 and 2 in the second step (Table 21).

Table 21 Increasing efficiency (2)

\begin{tabular}{cccc}
\hline$c_{1}$ & $c_{2}$ & $c_{3}$ & $C_{4}$ \\
\hline$S_{1}$ & $S_{4}$ & $S_{3}$ & $S_{2}$ \\
\hline
\end{tabular}

Source: Author

This allocation corresponds to the top trading cycle allocation. Accordingly, the modified deferred acceptance algorithm results in a Pareto-efficient allocation.
AN INCREASE IN THE SCHOOL'S RANK ON THE PREFERENCE LIST DUE TO ITS HIGHER QUALITY AND MINORITY STUDENTS

The deferred acceptance algorithm can be analyzed in terms of comparative statics, i.e. with respect to how the matching is modified due to the fact that some schools improve their quality. Due to the improved quality of schools, students should increase the ranking of a particular school on the list of their preferences. The deferred acceptance algorithm respects the improvement of school quality if the school is matched to the student with a higher priority after the school increases its quality. Let us consider the initial example and assume that School 3 improves its quality and that Student 3 puts School 3 at the top of the preference list (Table 22 and Table 23).

Table 22 Priorities

\begin{tabular}{cccc}
\hline$\succ_{c_{1}}$ & $\succ_{c_{2}}$ & $\succ_{c_{3}}$ & $\succ_{c_{4}}$ \\
\hline$s_{4}$ & $s_{1}$ & $s_{4}$ & $s_{2}$ \\
\hline$s_{2}$ & $s_{2}$ & $s_{3}$ & $s_{3}$ \\
\hline$s_{3}$ & $s_{3}$ & $s_{2}$ & $s_{1}$ \\
\hline$s_{1}$ & $s_{4}$ & $s_{1}$ & $s_{4}$ \\
\hline
\end{tabular}

Source: Author

Table 23 Preferences

\begin{tabular}{cccc}
\hline$\succ_{\mathrm{S}_{1}}$ & $\succ_{\mathrm{S}_{2}}$ & $\succ_{\mathrm{S}_{3}}$ & $\succ_{\mathrm{S}_{4}}$ \\
\hline $\mathrm{c}_{1}$ & $\mathrm{c}_{4}$ & $\mathrm{c}_{3}$ & $\mathrm{c}_{3}$ \\
\hline $\mathrm{c}_{2}$ & $\mathrm{c}_{3}$ & $\mathrm{c}_{1}$ & $\mathrm{c}_{4}$ \\
\hline $\mathrm{c}_{3}$ & $\mathrm{c}_{2}$ & $\mathrm{c}_{2}$ & $\mathrm{c}_{2}$ \\
\hline $\mathrm{c}_{4}$ & $\mathrm{c}_{1}$ & $\mathrm{c}_{4}$ & $\mathrm{c}_{1}$ \\
\hline
\end{tabular}

Source: Author

After this change, the application of the deferred acceptance algorithm generates the following matching (Table 24). 
Table 24 Increasing school quality

\begin{tabular}{cccc}
\hline$C_{1}$ & $C_{2}$ & $C_{3}$ & $C_{4}$ \\
\hline$S_{3}$ & $S_{1}$ & $S_{4}$ & $S_{2}$ \\
\hline
\end{tabular}

Source: Author

In this example, the improvement of the quality of School 3 is respected since it is matched to Student 4 instead of Student 3. However, it is easy to construct an example in which the deferred acceptance algorithm does not take into account the improvement of school quality. In addition, J. W. Hatfield, F. Kojima and Y. Narita (2017) prove that the Boston algorithm and the top trading cycle do not always respect the improvement of school quality.

Analyzing this problem of comparative statics in large markets, J. W. Hatfield, F. Kojima and Y. Narita (2017) prove that the deferred acceptance algorithm respects the improvement of school quality in large markets. In other words, after the improvement of school quality, as the size of the market increases, the probability that the school is matched to the student with a lower priority decreases. However, the Boston and the top trading cycle algorithms do not have this property in large markets. Accordingly, the deferred acceptance algorithm provides an incentive for schools to improve their quality, whereas the Boston and the top trading cycle algorithms are deprived of this feature.

Students differ according to their financial situation, social group, race, etc. The schools that are popular are located in the central parts of the city inhabited by wealthy students. Since schools determine their priorities based on the distance of the student's residence from school, the students who are not wealthy do not have a great opportunity to be enrolled in a popular school. For this reason, quotas are introduced for minority students in popular schools. In most cases, this policy brings minority students into a better position. However, F. Kojima (2012) argues that quotas may, in certain cases, make minority students worse off since majority students apply to other popular schools in which there is no quota, thereby reducing the possibility for minority students to enroll.
The following example illustrates the situation when the introduction of quotas makes minority students worse off. In this case, there are 3 students and 2 schools; School 1 has one place and School 2 has 2 places. The students' preferences and the school's priorities are shown in Table 25 and Table 26. Students 1 and 2 are majority students and Student 3 is a minority student.

Table 25 Preferences

\begin{tabular}{ccc}
\hline $\mathrm{s}_{1}$ & $\succ \mathrm{s}_{2}$ & $\succ \mathrm{s}_{3}$ \\
\hline $\mathrm{c}_{2}$ & $\mathrm{c}_{2}$ & $\mathrm{c}_{1}$ \\
\hline $\mathrm{c}_{1}$ & $\mathrm{c}_{1}$ & $\mathrm{c}_{2}$ \\
\hline
\end{tabular}

Source: Author

Table 26 Priorities

\begin{tabular}{cc}
\hline$\succ_{c_{1}}$ & $\succ_{c_{2}}$ \\
\hline$s_{1}$ & $s_{3}$ \\
\hline$s_{2}$ & $s_{2}$ \\
\hline$s_{3}$ & $s_{1}$ \\
\hline$q_{1}=1$ & $q_{2}=2$ \\
\hline
\end{tabular}

Source: Author

First, we will determine the allocation by assuming that there is no quota for minority students. The deferred acceptance algorithm, in which students make a proposal, generates the following allocation (Table 27):

Table 27 Minority students (1)

\begin{tabular}{cc}
\hline$C_{1}$ & $C_{2}$ \\
\hline$S_{3}$ & $S_{1}, S_{2}$ \\
\hline
\end{tabular}

Source: Author 
Now suppose that School 2 introduces a quota and reserves one place for the minority student 3 . The deferred acceptance algorithm results in the following allocation (Table 28):

Table 28 Minority students (2)

\begin{tabular}{cc}
\hline$C_{1}$ & $C_{2}$ \\
\hline$S_{1}$ & $S_{2}, S_{3}$ \\
\hline
\end{tabular}

Source: Author

After the introduction of the quota, the minority student 3 is matched to the less preferred School 2.

In addition to introducing a quota, another way to favor minority students is to change the priority so that minority students are given a higher priority than majority students, while the priorities within each of these groups stay the same. F. Kojima (2012) proves that the top trading cycle can also make minority students worse off if a quota is introduced for these students or if priorities are changed in their favor.

To reduce the problem that occurs when minority students are made worse off by the introduction of quotas, I. Hafalir, B. Yenmez and M. Yildrim (2013) suggest the use of flexible quotas instead of fixed quotas. When a fixed quota is applied, the school is unable to enroll majority students in the quota for the minority ones, even though there is no sufficient number of minority students to fill the quota. With a flexible quota, the school first enrolls minority students within their quota, whereas the empty places within this quota can be filled with majority students. The simulation analysis carried out by the authors shows that the number of minority students that are better off in the deferred acceptance algorithm and the top trading cycle with a flexible quota is significantly greater than the number of minority students, who are in a better position in the algorithms with a fixed quota.

\section{THE LIMITED LIST OF PREFERENCES}

In the previous discussion, we have assumed that students can submit the list of their preferences of an unlimited length. In reality, students have a limit on the length of the list of preferences. In New York, for example, choice is limited to maximum twelve schools, whereas in Boston, it was impossible to specify up to five schools before 2006. With this assumption, it is no longer certain that the deferred acceptance algorithm and the top trading cycle will be incentivecompatible. In other words, in these algorithms, with the limited length of the list of preferences, it is necessary to determine the Nash equilibrium, as well as in the Boston algorithm, without this limitation. Therefore, G. Haeringer and F. Klijn (2009) determine the Nash equilibrium in the algorithms with a limited list of preferences in the Boston mechanism, the deferred acceptance algorithm and the top trading cycle. An important result of this paper is that the Nash equilibria in the Boston algorithm and in the top trading cycle are independent of the length of preferences. On the other hand, the Nash equilibria in the deferred acceptance algorithm have a hierarchical relationship, which means that the Nash equilibrium in the algorithm with a shorter list of preferences is the Nash equilibrium in the algorithm with a longer list of preferences.

The determination of the Nash equilibrium in the deferred acceptance algorithm can be illustrated by an example taken from G. Haeringer and F. Klijn (2009). In this example, there are 3 students and 3 schools, and each school can accept one student. The length of the list of preferences is limited to 2 schools. Table 29 shows the preferences of the students with an unlimited length of the list of preferences, the preferences of a limited length, as well as the priorities of the schools.

By applying the deferred acceptance algorithm, in which students make a proposal, on the basis of the preferences of a limited length, the allocation: $\left[\left(s_{1}, c_{1}\right)\right.$, $\left.\left(s_{2}, c_{2}\right),\left(s_{3^{\prime}} c_{3}\right)\right]$ is obtained. In this allocation, there is justified envy since Student 2 prefers School 3 and has a higher priority in that school than Student 3. Here, the result obtained differs from the earlier 
conclusions because the Nash equilibrium allocation in the deferred acceptance algorithm does not have to be stable when the length of the preference list is limited.

Table 29 Limited list of preferences

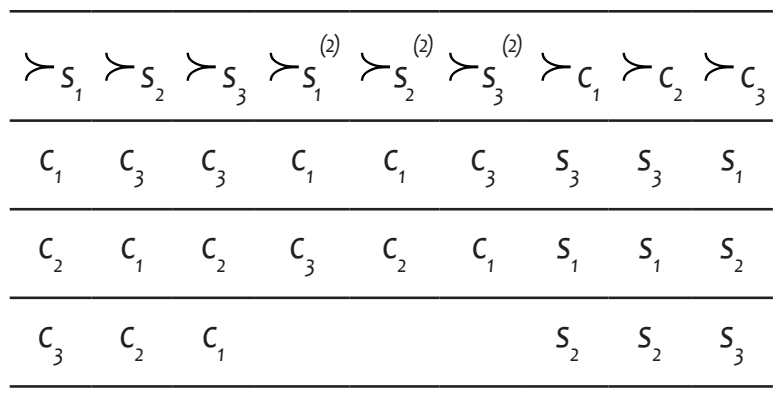

Source: Haeringer \& Klijn, 2009

In order to obtain a stable matching in the deferred acceptance algorithm with a limited length of preferences, school priorities must satisfy F. Ergin's acyclicity condition (2002). In the top trading cycle, a stable allocation is not achieved even when there is no limit on the length of the list of preferences. Therefore, in this case, school priorities must satisfy a stricter condition called O. Kesten's acyclicity condition (2006). These conditions include two sub-conditions. The cyclic condition is based on the fact that school priorities form a cycle, such that for example Student 1 has a higher priority in School 1 than Student 3, and Student 3 has a higher priority than Student 1 in School 2. If both schools have the same priorities, the cyclic condition is never fulfilled. The second sub-condition is rarity, which implies that there are a significant number of students applying for places in schools. If each school has the number of seats equal to the number of students, the rarity condition is never met. As the number of places in a school decreases compared to the total number of students, competition for available places is more intensive.

For the top trading cycle allocation to be efficient with the limited length of the list of preferences, it is necessary that school priorities satisfy the $X$-acyclicity, while the efficiency of the deferred acceptance algorithm needs a stricter requirement for school priorities called the strong $X$-acyclicity.

\section{INDIFERENCES IN SCHOOL CHOICE}

In the previous discussion, we have assumed that schools have strict priorities when ranking students. In reality, however, students belong to priority groups and schools are indifferent between students within the same group, whereas there is a strict priority between different groups. Matching algorithms cannot be applied in the case when priorities are not strict and it is necessary to transform weak priorities into strict priorities. One option for the indifference problem suggested by A. Erdil and $\mathrm{H}$. Ergin (2008) is that the students who have a lower index within the same priority group have a higher priority. For example, if Students 1, 2 and 3 belong to the same group, Student 1 has the highest priority and is followed by Student 2 and student 3. Such an arbitrary rule does not guarantee that the allocation in the deferred acceptance algorithm is stable. Therefore, A. Erdil and H. Ergin (2008) propose a stable improvement cycle in order to transform an arbitrary matching into a stable matching.

In addition to the previous option, for the indifference problem in school choice, A. Abdulkardiroğlu, P. Pathak and A. Roth (2009) propose single and multiple tie-breaking rules for the resolution of indifference. In Multiple tie-breaking (DA-MTB), each student is assigned a different lottery number in each school, whereas in Single tie-breaking (DA-STB), each student is assigned the same lottery number in each school. It is possible to prove that the average ranking of the schools which students are enrolled in is higher on their list of preferences in the DA-STB than in the DAMTB.

All of the previous methods have in common that students do not have any influence on the generation of strict priorities from weak priorities. This problem can further be improved by applying the deferred acceptance algorithm, in which students have the opportunity to influence the resolution of indifference. This algorithm was constructed by A. Abdulkadiroğlu, Y-K. Che and Y. Yasuda (2015) and it is referred to as Choice-Augmented Deferred Acceptance (CADA). A simplified explanation for this algorithm can be illustrated by the following example, 
in which there are three students and three schools, and each school can only enroll one student. All the students belong to the same priority group, which means that the schools are indifferent between them. The students have the following cardinal utilities for different schools (Table 30).

Table 30 Cardinal utilities and school choice

\begin{tabular}{cccc}
\hline & $u\left(s_{1}\right)$ & $u\left(s_{2}\right)$ & $u\left(s_{3}\right)$ \\
\hline$c_{1}$ & 4 & 4 & 3 \\
\hline$c_{2}$ & 1 & 1 & 2 \\
\hline$c_{3}$ & 0 & 0 & 0 \\
\hline
\end{tabular}

Source: Abdulkardiroğlu, Che \& Yasuda, 2015

First, we will determine the allocation in the deferred acceptance algorithm, in which indifference is resolved such that each student receives a lottery number from a uniform distribution. By generating strict priorities in this way, each student has the same probability of $1 / 3$ to enroll in any school, so that each student has the expected utility of $5 / 3$. However, a Pareto improvement is possible in this case. Student 3 has a higher level of utility if he is enrolled in School 2, which is his second best choice compared to Students 1 and 2, and the matching in which Student 3 is certainly enrolled in School 2, whereas Students 1 and 2 are enrolled in Schools 1 and 3, with the probability of $1 / 2$, is Pareto-superior to the initial situation, when all students participate in the lottery. In the latter case, each student has an expected utility of 2, which is higher than the level of the expected utility of $5 / 3$. In order to obtain this matching, each student needs to be offered a choice between certain enrolment in School 2 and the lottery, in which he is enrolled in School 1 and School 3, with an equal probability. Students 1 and 2 will choose the lottery, and Student 3 will choose safe enrolment in School 2.

The matching that we have previously described can be achieved with the CADA algorithm. In this algorithm, students submit a list of their preferences and one target school. In the resolution of indifference in a particular school, the students who have indicated that school as the target have a priority. Each student receives two lottery numbers drawn from a uniform distribution. The first lottery number that the student receives is the target lottery number, and the second is the regular lottery number. In the determination of strict priorities, the target lottery number is first considered, and then the regular lottery number is considered. Once indifferences have been resolved, the deferred acceptance algorithm is applied.

Generating strict priorities based on the target and the regular lottery numbers can be illustrated by way of the example in which there are ten students and two schools. Students: 1, 3, 5, 7, and 9 target School 1 and Students: 2, 4, 6, 8, and 10 target School 2. Suppose that the students obtain the following target: T(I), and regular: $R(I)$, lottery numbers:

$T(I): 7,1,2,8,3,4,9,5,6,10 ; \quad R(I): 7,2,4,3,5,8,9,6,10,1$.

For the students with the odd index, who have targeted School 1, the priority is determined based on the target lottery number, and the priority of the students in the first school is: 7, 1,3, 9, 5. After that, the priority of the students who have not targeted School 1 is determined on the basis of the regular lottery number, so that the complete order of the priorities in the first school is: 7, 1, 3, 9, 5, 2, 4, 8, 6, 10. The second school is targeted by the students with the even index and based on the target lottery number, the priority for these students is: $2,8,4,6,10$. The priority for other students is determined and it is based on the regular lottery number, thus the complete priority order in the second school being: 2, 8, 4, 6, 10, 7, 3, 5, 9, 1 .

The simulation analysis conducted by A. Abdulkadiroğlu, Y-K. Che and Y. Yasuda (2015) shows that in the deferred acceptance algorithm with the multiple tie-breaking rule, a smaller number of students are enrolled in the first choice schools compared with the deferred acceptance algorithm with the single tie-breaking rule and the deferred acceptance algorithm with a choice. As regards the last two algorithms, when the number of the students enrolled in the first choice schools is compared, there is no significant difference between them. However, the deferred acceptance algorithm with a choice has 
an advantage over the deferred acceptance algorithm with the single tie-breaking rule for the students enrolled in the school that is their $k$-th best choice, because these students have a higher utility in the CADA algorithm.

\section{CONCLUSION}

In this paper, we have presented the most important results in matching students to schools by using the simplified examples, thus making this field closer to a broader audience. We have seen that there are some limiting factors in the application of the matching algorithms. First, the deferred acceptance algorithm is not efficient, which is its main drawback. The second limiting factor in the application of the matching algorithms is the limit of the preference list that students can submit, which undermines the stability of matching. From the practical point of view, students should have a possibility of submitting a sufficiently long list of schools so that the length of the preference list is not a limiting factor. In reality, the vast majority of students submit their preferences for several schools, which implies that the limit on the length of the preference list is not so important in practical application.

We have shown in the paper that cooperative game theory is possible to apply in matching problems. Moreover, we have seen that it is possible to make incentive-compatible mechanisms where students reveal their preferences.

The previous conclusions are implicative of the fact that the relationship between the theoretical models and practice is bidirectional. The absence of the price mechanism has imposed the need for the creation of the alternative rules as a substitute for the market. On the other hand, the existing theoretical knowledge in cooperative game theory and the mechanism design has enabled the achievement of this objective and the finding out of a solution to the practical problem.

The matching algorithms have proved to be very successful in determining the optimal allocation in the situations in which the market mechanism cannot be used for legal or ethical reasons. Beside their application to the matching of students to schools, the algorithms have been successfully applied to the matching of doctors to hospitals, matching organ donors to patients, the allocation of parking spaces or offices, and so on. In addition to matching students to schools, their especially significant application is that in matching organ donors to patients, where the incompatibility problem is greatly reduced.

Matching students to schools is of great importance in the Republic of Serbia since the algorithm of immediate matching is still used and this paper proposes the improvements that could be achieved by applying the deferred acceptance algorithm.

It would be interesting for further research to analyze an increase in students' welfare if the deferred acceptance algorithm is used instead of the immediate matching algorithm. However, based on the historical data, the limiting factor in this analysis is that only information on the stated preferences is available and it is known that the immediate matching algorithm does not induce a true preference revelation. Therefore, based on the historical data, it is possible to determine an increase in welfare only for the stated preferences, i.e. an increase in welfare inclusive of this constraint.

\section{REFERENCES}

Abdulkadiroğlu, A. (2013). School choice. In N. Vulkan, A. E. Roth \& Z. Neeman (Eds.), The Handbook of Market Design (pp. 138-169). Oxford, UK: Oxford University Press.

Abdulkadiroğlu, A., Che, Y-K., \& Yasuda, Y. (2015). Expanding "choice" in school choice. American Economic Journal: Microeconomics, 7(1), 1-42. doi: 10.1257/ mic. 20120027

Abdulkardiroğlu, A., \& Sönmez, T. (2003). Social choice: A mechanism design approach. American Economic Review, 93(3), 729-747. doi: 10.1257/000282803322157061

Abdulkardiroğlu, A., Pathak, P., \& Roth, A. (2005a). The New York city high school match. American Economic Review, 95(2), 364-367. doi: 10.1257/000282805774670167 
Abdulkardiroğlu, A.,Pathak,P., RothA., \&Sönmez, T.(2005b). The Boston public school match. American Economic Review, 95(2), 368-371. doi: 10.1257/000282805774669637

Abdulkardiroğlu, A., Pathak, P., \& Roth, A. (2009). Strategy-proofness versus efficiency in school choice with indifferences: Redesigning the NYC school match. American Economic Review, 99(5), 1954-1978. doi: 10.1257/ aer.99.5.1954

Backović, M. i Popović, Z. (2012). Matematičko modeliranje i optimizacija. Beograd, Republika Srbija: Ekonomski fakultet Univerziteta u Beogradu.

Backović, M., Popović, Z., \& Stamenković, M. (2016). Reflexive game theory approach to mutual insurance problem. Montenegrin Journal of Economics, 12(3), 87-100. doi: 10.14254/1800-5845.2016/12-3/6

Erdil, A., \& Ergin, H. (2008). What's the matter with tie-breaking? Improving efficiency in school choice. American Economic Review, 98(3), 669-689. doi: 10.1257/ aer.98.3.669

Ergin, H., \& Sönmez, T. (2006). Games of school choice under Boston mechanism. Journal of Public Economics, 90(1-2), 215-237. doi:10.1016/j.jpubeco.2005.02.002

Ergin, H. (2002). Efficient resource allocation on the basis of priorities. Econometrica, 70(6), 2489-2497. doi: 10.1111/j.1468-0262.2002.00447.x

Gale, D., \& Shapely, L. (1962). College admission and the stability of marriage. American Mathematical Monthly, 69(1), 9-15.

Gale, D., \& Scarf, H. (1974). On cores and indivisibility. Journal of Mathematical Economics, 1, 23-37.

Haeringer, G., \& Klijn, F. (2009). Constrained school choice. Journal of Economic Theory, 144(5), 1921-1947. doi. org/10.1016/j.jet.2009.05.002

Hafalir, I., Yenmez B., \& Yildirim, M. (2013). Effective Affirmative Action in School Choice. Theoretical Economics 8(2), 325-363. doi: 10.3982/te1135
Hatfield, J. W., Kojima, F., \& Narita, Y. (2017). Promoting school competition through school choice: A market design approach. Journal of Economic Theory. (Forthcoming)

Kesten, O. (2006). On two competing mechanisms for priority based allocation problems. Journal of Economic Theory, 127, 155-171. doi: 10.1016/j.jet.2004.11.001

Kesten, O. (2010). School choice with consent. Quarterly Journal of Economics, 125(3), 1297-1348. doi: https://doi. org/10.1162/qjec.2010.125.3.1297

Kojima, F. (2012). School choice: Impossibilities for affirmative action. Games and Economic Behavior, 75(2), 685-693. doi.org/10.1016/j.geb.2012.03.003

Kojima, F., \& Pathak, P. (2009). Incentives and stability in large two-sided matching markets. American Economic Review, 99(3), 608-627. doi: 10.1257/aer.99.3.608

Kojima, F., \& Ünver, U. (2014). The "Boston" school-choice mechanism: An axiomatic approach. Economic Theory, 55(3), 515-544. doi:10.1007/s00199-013-0769-8

Pathak, P., \& Sönmez, T. (2008). Leveling the playing field: Sincere and sophisticated players in the the Boston mechanism. American Economic Review, 98(4), 1636-1652. doi: 10.1257/aer.98.4.1636

Roth, A. (1985). The college admission problem is not equivalent to the marriage problem. Journal of Economic Theory, 36(2), 277-288. doi: 10.1016/0022-0531(85)90106-1

Roth, A. (2015). Who Gets What - And Why. New York, NY: Houghton Mifflin Harcourt Publishing Company.

Sönmez, T. (1997). Manipulation via capacities in two-sided matching markets. Journal of Economic Theory, 77(1), 197204. doi.org/10.1006/jeth.1997.2316 


\section{Received on $18^{\text {th }}$ April 2017, after one revision, accepted for publication on $23^{\text {rd }}$ August 2017. Published online on $25^{\text {th }}$ August 2017.}

Dejan Trifunovic is an Associate Professor at the Faculty of Economics, University of Belgrade, Belgrade, the Republic of Serbia. He teaches the undergraduate courses in Microeconomics and Industrial Organization, and the master and $\mathrm{PhD}$ courses in Microeconomics. His scientific interest is that in game theory, auctions, matching, asymmetric information and network externalities. 


\title{
UPARIVANJE UČENIKA I ŠKOLA
}

\author{
Dejan Trifunović* \\ Ekonomski fakultet Univerziteta u Beogradu
}

U ovom radu prikazujemo problem uparivanja učenika i škola pomoću različitih mehanizama uparivanja. Ovo tržište je specifično po tome što su državne škole besplatne i nije moguće koristiti cenovni mehanizam koji bi izvršio optimalnu alokaciju učenika u škole. Stoga je potrebno koristiti različite algoritme uparivanja koji simuliraju tržišni mehanizam, i pomoću kojih određujemo jezgro kooperativne igre. U ovom radu ćemo utvrditi da je moguće primeniti kooperativnu teoriju igara u problemima uparivanja. Rad je preglednog karaktera i kroz ilustrativne primere ćemo porediti algoritme uparivanja sa aspekta kompatibilnosti podsticaja, stabilnosti uparivanja i efikasnosti. U radu ćemo prikazati i neke specifične probleme koji se mogu javiti kod uparivanja kao što su poboljšanje kvaliteta škole, favorizovanje manjinskih učenika, ograničena dužina liste preferencija i generisanje striktnih prioriteta na osnovu slabih prioriteta.

Ključne reči: uparivanje, bostonski algoritam, algoritam odloženog prihvatanja, algoritam najviših ciklusa trgovanja

\section{JEL Classification: $\mathrm{C} 78$}

\section{UVOD}

Najvažnija uloga koju cene imaju na tržištu je da vrše optimalnu alokaciju resursa. Međutim, postoje određene situacije kad cenovni mehanizam nije moguće primeniti, ali je i dalje potrebno optimalno alocirati resurse. Primer predstavlja upis učenika u državne srednje škole koje su besplatne. Stoga je potrebno konstruisati algoritam uparivanja koji simulira funkcionisanje tržišta. Dakle, predmet istraživanja u ovom radu je uparivanje učenika i škola

* Korespondencija: D. Trifunović, Ekonomski fakultet Univerziteta u Beogradu, Kamenička 6, 11000 Beograd, Republika Srbija; e-mail: dejan@ekof.bg.ac.rs u odsustvu novčanih transfera, dok je cilj istraživanja da ukaže na veliku praktičnu primenu algoritama uparivanja na ovom tržištu.

Sa metodološkog aspekta, algoritmi uparivanja zasnivaju se na primeni kooperativne teorije igara i oblikovanja ekonomskog mehanizma.

Osnovna podela igara je na kooperativne i nekooperativne igre. Kod nekooperativnih igara igrač nastoji da maksimizira svoju isplatu za dati skup pravila igre (Backović i Popović, 2012). Kod kooperativnih igara igrači formiraju koalicije i strategija je definisana na nivou koalicije (Backović, Popović \& Stamenković, 2016). Kod kooperativnih 
igara potrebno je odrediti jezgro igre kad ne postoji ni jedna koalicija aktera koja može da ostvari poboljšanje $\mathrm{u}$ Paretovom smislu u odnosu na alokaciju koja se nalazi u jezgru.

Oblikovanje ekonomskog mehanizma se zasniva na pretpostavci da akteri poseduju privatne informacije koje saopštavaju centru mehanizma. Mehanizam treba da bude zasnovan na takvim pravilima koja navode svakog aktera da istinito otkrije svoje privatne informacije. Ovakav mehanizam je kompatibilno podsticajan.

Prva hipoteza na kojoj se zasnivaju modeli uparivanja je da je pomoću algoritama uparivanja moguće odrediti jezgro kooperativne igre i odrediti alokaciju koja bi se ostvarila u tržišnom mehanizmu u kom bi bilo moguće vršiti novčane transfere. Druga hipoteza je da je moguće kreirati algoritme uparivanja koji su kompatibilno podsticajni.

Ovaj rad je, pre svega, preglednog karaktera, ali će kroz originalne primere biti na koncizan način ilustrovani postojeći rezultati.

Prilikom izbora mehanizma uparivanja potrebno je voditi računa o tome da učenici imaju podsticaj da istinito iskažu svoje preferencije, da uparivanje bude stabilno i efikasno.

A. Roth (2015) navodi da je mehanizam uparivanja, koji je korišćen u Njujorku do 2003, bio vrlo složen. Ovde je korišćen algoritam trenutnog uparivanja koji funkcioniše na sledeći način. Učenici su navodili listu od tri škole koje žele da upišu. Na osnovu pristiglih prijava, škola upisuje učenike sa najvećim prioritetom koji su tu školu naveli kao najbolji izbor. Ukoliko škola popuni kapacitet u prvom krugu, odbija višak prijavljenih učenika. U sledećem krugu učenici koji su prethodno odbijeni prijavljuju se u školu koja je njihov drugi najbolji izbor. Škola u kojoj je ostalo slobodnih mesta upisuje prijavljene učenike sa najvećim priorietom do svog kapaciteta i odbija višak prijavljenih učenika. Ista procedura se primenjuje $u$ trećem krugu. S obzirom na karakteristike algoritma, nije bilo potrebno da učenici navedu više od tri škole koje žele da upišu, jer je verovatnoća da budu upisani u školu koja je njihov četvrti najbolji izbor bila zanemarljiva. Učenici koji nisu upisani ni nakon trećeg kruga raspoređivani su administrativnim putem u škole u kojima je bilo slobodnih mesta. Ovaj algoritam je bio vrlo neefikasan jer je skoro trećina učenika upisivana na ovaj način. Na osnovu podataka o navedenim preferencijama, može se utvrditi da je oko $80 \%$ učenika upisano u škole koje su naveli kao prvi izbor. Međutim, učenici u ovom algoritmu nemaju podsticaj da istinito iskažu svoje preferencije, pa je škola koja je navedena kao prvi najbolji izbor $\mathrm{u}$ najvećem broju slučajeva predstavljala strateški izbor. Drugim rečima, škola koja je navedena kao najbolji izbor je predstavljala školu u kojoj je postojala najveća verovatnoća da učenik bude primljen i često ta škola nije bila na vrhu liste preferencija. Detaljnija analiza algoritma trenutnog uparivanja je data u sledećim radovima: A. Abdulkardiroglu, A. Pathak i A. Roth (2005; 2009); A. Abdulkardiroglu, A. Pathak, A. Roth i T. Sonmez (2005). Imajući u vidu sve ove probleme, A. Roth je sa svojim saradnicima predložio upotrebu algoritma odloženog prihvatanja, koji vrši privremeno uparivanje. Za primenu ovog algoritma A. Roth je 2012. dobio Nobelovu nagradu za ekonomiju, zajedno sa L. Chapley-em.

Algoritam odloženog prihvatanja prvi su razmatrali D. Gale i L. Chapley (1962). Navođenje liste preferencija u algoritmu odloženog prihvatanja mnogo je jednostavnije. Naime, učenik ne mora da navede školu za koju smatra da ima najveću verovatnoću da bude upisan kao svoj najbolji izbor, jer neće izgubiti prioritet u toj školi u odnosu na učenika koji ima niži prioritet kao što je to slučaj $\mathrm{u}$ algoritmu trenutnog uparivanja. Dakle, učenik istinito navodi preferencije u ovom algoritmu. Ovaj mehanizam dovodi do stabilnog uparivanja, što znači da nije moguće naći školu i učenika koji nisu međusobno upareni, a koji bi preferirali da budu upareni u odnosu na uparivanje koje je im je određeno u algoritmu. Drugim rečima, u stabilnoj alokaciji ne postoji opravdana zavist. Ovaj algoritam se pokazao znatno uspešnijim od algoritma trenutnog uparivanja, i broj učenika koji su upisani administrativnim putem $\mathrm{u}$ Njujorku smanjen je za deset puta. Istovremeno, bilo je mnogo više učenika koji su upisani u školu koja je njihov najbolji izbor, kao i broj učenika koji su upisani u školu koja je njihov drugi najbolji izbor, itd. Za uparivanje je izabran 
algoritam odloženog prihvatanja, iako je razmatran i algoritam najviših ciklusa trgovanja, koji su uveli D. Gale i H. Scarf (1974). I u ovom mehanizmu učenici istinito saopštavaju preferencije.

Kad su u pitanju prioriteti škola, oni se određuju na osnovu udaljenosti mesta stanovanja učenika od škole, i na osnovu toga da li učenik ima brata ili sestru koji već idu u tu školu. Učenici koji stanuju bliže školi imaju veći prioritet kao i oni čiji brat ili sestra su upisani u tu školu. Prioriteti mogu da budu određeni egzogeno kad ih školama dostavlja neki administrativni organ, kao što je to slučaj u Bostonu. U ovom slučaju, reč je o jednostranom uparivanju, jer su preferencije učenika važnije od egzogeno određenih prioriteta. Druga mogućnost je da prioritete određuju škole, kao što je slučaj u Njujorku. U ovom slučaju prioritete možemo da posmatramo kao preferencije, i tada se radi o problemu dvostranog uparivanja. Kod dvostranog uparivanja, preferencije škola su podjednako važne kao i preferencije učenika, za razliku od jednostranog uparivanja gde su bitne samo preferencije učenika. U problemu jednostranog uparivanja, stabilna alokacija ne mora da bude optimalna u Paretovom smislu, za razliku od dvostranog uparivanja gde ne postoji razlika između ova dva cilja. Kad je u pitanju kompatibilnost podsticaja, odnosno, istinitost iskazivanja preferencija od strane učenika, A. Abdulkadiroglu (2013) smatra da algoritam sa ovom osobinom značajno olakšava učeniku da navede listu svojih preferencija.

Ostatak rada je organizovan na sledeći način. U drugom delu prikazujemo načine funkcionisanja bostonskog algoritma, algoritma odloženog prihvatanja i algoritma najviših ciklusa trgovanja. U trećem delu sledi detaljna analiza ovih algoritama sa aspekta kompatibilnosti podsticaja, stabilnosti i efikasnosti. Četvrti deo razmatra da li algoritmi uparivanja uvažavaju pobojšanje rangiranja škole na listi preferencija usled povećanja njenog kvaliteta kao i upisnu politiku koja favorizuje manjinske učenike. U petom delu se analiziraju osobine algoritama uparivanja u slučaju ograničene dužine liste preferencija koju učenici mogu da navedu. U šestom delu su prikazani različiti načini za kreiranje striktnih prioriteta na osnovu slabih prioriteta, nakon čega slede zaključna razmatranja.

\section{ALGORITMI UPARIVANJA}

Algoritme uparivanja možemo da ilustrujemo pomoću sledećeg primera. Pretpostavimo da imamo četiri škole $\left(c_{1^{\prime}}, c_{2^{\prime}}, c_{3^{\prime}} c_{4}\right)$ sa po jednim mestom i četiri učenika $\left(s_{1}, s_{2}, s_{3}, s_{4}\right)$. Preferencije i prioriteti su prikazani u Tabeli 1 i Tabeli 2.

Tabela 1 Prioriteti

\begin{tabular}{cccc}
\hline$\succ_{\mathrm{C}_{1}}$ & $\succ_{\mathrm{C}_{2}}$ & $\succ_{\mathrm{c}_{3}}$ & $\succ_{\mathrm{C}_{4}}$ \\
\hline $\mathrm{s}_{4}$ & $\mathrm{~s}_{1}$ & $\mathrm{~s}_{4}$ & $\mathrm{~s}_{2}$ \\
\hline$s_{2}$ & $s_{2}$ & $s_{3}$ & $s_{3}$ \\
\hline$s_{3}$ & $s_{3}$ & $s_{2}$ & $s_{1}$ \\
\hline$s_{1}$ & $s_{4}$ & $s_{1}$ & $s_{4}$ \\
\hline
\end{tabular}

Izvor: Autor

Tabela 2 Preferencije

\begin{tabular}{cccc}
\hline$\tau_{\mathrm{s}_{1}}$ & $\succ_{\mathrm{s}_{2}}$ & $\succ_{\mathrm{s}_{3}}$ & $\succ_{\mathrm{s}_{4}}$ \\
\hline $\mathrm{c}_{1}$ & $\mathrm{c}_{4}$ & $\mathrm{c}_{1}$ & $\mathrm{c}_{4}$ \\
\hline $\mathrm{c}_{2}$ & $\mathrm{c}_{3}$ & $\mathrm{c}_{2}$ & $\mathrm{c}_{2}$ \\
\hline$c_{3}$ & $c_{2}$ & $c_{4}$ & $\mathrm{c}_{1}$ \\
\hline$c_{4}$ & $c_{1}$ & $c_{3}$ & $c_{3}$ \\
\hline
\end{tabular}

Izvor: Autor

Prvo ćemo predstaviti bostonski algoritam, u kome se vrši trenutno uparivanje. Svaki učenik upućuje predlog školi koja je njegov najbolji izbor. Škola zadržava učenika sa najvećim prioritetom i odbija ostale. U narednom koraku, učenici koji su odbijeni prijavljuju se u školu koja je drugi najbolji izbor, pri čemu škole zadržavaju učenike sa najvećim prioritetom. Postupak se ponavlja sve dok svi učenici ne budu upareni sa školama.

$\mathrm{U}$ prethodnom primeru, $\mathrm{u}$ prvom koraku, učenici $1 \mathrm{i}$ 3 prijavljuju se u školu 1, a učenici 2 i 4 se prijavljuju u školu 4 (Tabela 3). 
Tabela 3 Bostonski algoritam (1)

\begin{tabular}{cccc}
\hline$C_{1}$ & $C_{2}$ & $c_{3}$ & $c_{4}$ \\
\hline$s_{1}, s_{3}$ & & & $s_{2}, s_{4}$ \\
\hline
\end{tabular}

Izvor: Autor

Škola 1 zadržava učenika 3 koji ima veći prioritet, a škola 4 zadržava učenika 2. U narednom koraku, učenici 1 i 4 se prijavljuju u školu 2 (Tabela 4).

Tabela 4 Bostonski algoritam (2)

\begin{tabular}{llll}
\hline$C_{1}$ & $C_{2}$ & $C_{3}$ & $C_{4}$ \\
\hline$S_{3}$ & & $S_{2}$ \\
\hline & $S_{1} S_{4}$ & \\
\hline
\end{tabular}

Izvor: Autor

Škola 2 zadržava učenika 1 koji ima veći prioritet. U narednom koraku, učenik 4 se prijavljuje u školu 1, ali ovde nema slobodnih mesta. U poslednjem koraku učenik 4 se prijavljuje u školu 3 sa kojom je uparen. Dakle, u bostonskom algoritmu imamo sledeće uparivanje (Tabela 5).

Tabela 5 Bostonski algoritam (3)

\begin{tabular}{cccc}
\hline$C_{1}$ & $C_{2}$ & $C_{3}$ & $C_{4}$ \\
\hline$S_{3}$ & $S_{1}$ & $S_{4}$ & $S_{2}$ \\
\hline
\end{tabular}

Izvor: Autor

U algoritmu odloženog prihvatanja, učenik i škola su privremeno upareni, i škola može da odbije učenika sa kojim je trenutno uparena $\mathrm{u}$ korist učenika sa većim prioritetom koji se prijavi kasnije. U prvom koraku situacija je ista kao u bostonskom algoritmu (Tabela 6).
Tabela 6 Algoritam odloženog prihvatanja (1)

\begin{tabular}{cccc}
\hline$C_{1}$ & $C_{2}$ & $C_{3}$ & $C_{4}$ \\
\hline$S_{1} S_{3}$ & & & $S_{2}, s_{4}$ \\
\hline
\end{tabular}

Izvor: Autor

Ista situacija se ponavlja i u drugom koraku, kad se učenici 1 i 4 prijavljuju u školu 2 (Tabela 7).

Tabela 7 Algoritam odloženog prihvatanja (2)

\begin{tabular}{llll}
\hline$c_{1}$ & $C_{2}$ & $c_{3}$ & $c_{4}$ \\
\hline$s_{3}$ & & & $s_{2}$ \\
\hline & $S_{1} s_{4}$ & \\
\hline
\end{tabular}

Izvor: Autor

U trećem koraku, učenik 4 se prijavljuje u školu 1 (Tabela 8).

Tabela 8 Algoritam odloženog prihvatanja (3)

\begin{tabular}{llll}
\hline$C_{1}$ & $C_{2}$ & $C_{3}$ & $C_{4}$ \\
\hline$S_{3}$ & & & $S_{2}$ \\
\hline & $S_{1}$ & \\
\hline$S_{4}$ & & & \\
\hline
\end{tabular}

Izvor: Autor

Škola 1 sada zadržava učenika 4 kao najbolji izbor i odbija učenika 3, koji se u narednom koraku prijavljuje u školu 2 (Tabela 9).

Tabela 9 Algoritam odloženog prihvatanja (4)

\begin{tabular}{llll}
\hline$C_{1}$ & $C_{2}$ & $C_{3}$ & $C_{4}$ \\
\hline & & & $S_{2}$ \\
\hline$S_{4}$ & $S_{1}$ & \\
\hline & $S_{3}$ & \\
\hline
\end{tabular}

Izvor: Autor 
Škola 2 zadržava učenika 1, kao najbolji izbor, i u poslednjem koraku učenik 3 se prijavljuje u školu 3 sa kojom je uparen (Tabela 10).

Tabela 10 Algoritam odloženog prihvatanja (5)

\begin{tabular}{cccc}
\hline$C_{1}$ & $C_{2}$ & $c_{3}$ & $C_{4}$ \\
\hline$S_{4}$ & $S_{1}$ & $S_{3}$ & $S_{2}$ \\
\hline
\end{tabular}

Izvor: Autor

U algoritmu najviših ciklusa trgovanja, učenik povlači strelicu prema školi koja je njegov najbolji izbor, i škola povlači strelicu prema učeniku sa najvećim prioritetom. Ciklus započinje sa učenikom $i$, koji povlači strelicu prema školi $k$, koja povlači strelicu prema učeniku $j$, itd, pri čemu poslednja škola u nizu povlači strelicu prema učeniku $i$, od koga je započeo ciklus. Učenici u ciklusu su upareni sa školama prema kojima povlače strelicu i uklanjaju se iz algoritma. Postupak se ponavlja dok svi učenici ne budu upareni.

U prvom koraku imamo sledeću situaciju (Slika 1):

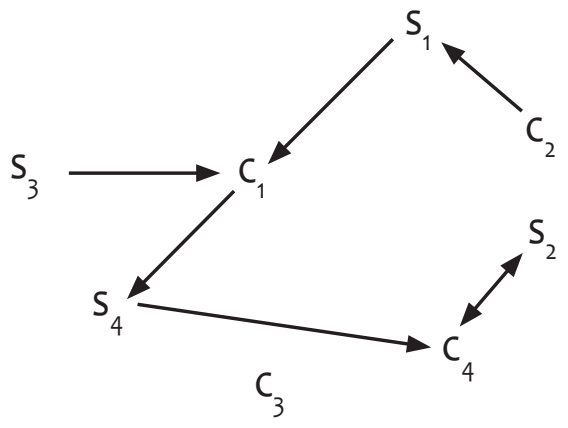

Slika 1 Algoritam najviših ciklusa trgovanja (1)

Izvor: Autor

Na osnovu Slike 1 možemo da utvrdimo da postoji jedan ciklus koji čine škola 4 i učenik 2, koji su upareni i uklanjaju se iz algoritma.

U drugom koraku algoritma, učenici i škole povlače strelicu prema preostalim školama i učenicima koji su njihov najbolji izbor (Slika 2).

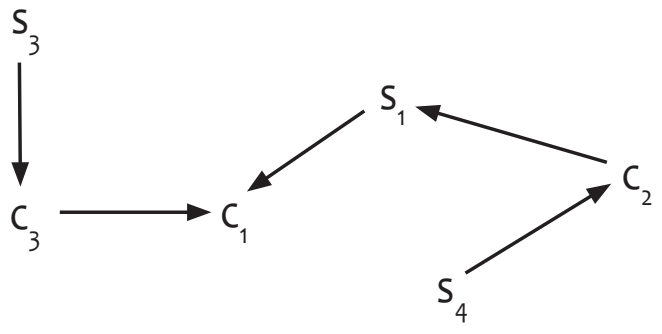

Slika 2 Algoritam najviših ciklusa trgovanja (2)

Izvor: Autor

Na osnovu Slike 2, vidimo da postoji jedan ciklus koji čine $\left(s_{1}, c_{1}, s_{4^{\prime}}, c_{2}\right)$. Dakle, učenik 1 je uparen sa školom 1 i učenik 4 je uparen sa školom 2.

U poslednjem koraku, imamo jedan ciklus, i škola 3 je uparena sa učenikom 3 (Slika 3).

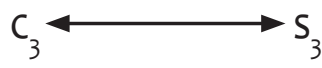

Slika 3 Algoritam najviših ciklusa trgovanja (3)

Izvor: Autor

Prema tome, $\mathrm{u}$ algoritmu najviših ciklusa trgovanja imamo sledeću alokaciju (Tabela 11).

Tabela 11 Najviši ciklusi trgovanja

\begin{tabular}{cccc}
\hline$C_{1}$ & $C_{2}$ & $C_{3}$ & $C_{4}$ \\
\hline$S_{1}$ & $S_{4}$ & $S_{3}$ & $S_{2}$ \\
\hline
\end{tabular}

Izvor: Autor

Ukoliko uporedimo alokaciju u algoritmu najviših ciklusa trgovanja i alokaciju koja se ostvaruje $u$ algoritmu odloženog prihvatanja, vidimo da u prvoj alokaciji postoji opravdana zavist kad postoje učenik $i$ i škola $j$, tako da učenik $i$ preferira školu $j$ u odnosu na školu sa kojom je uparen u algoritmu, dok u školi $j$ učenik $i$ ima veći priritet od učenika $l$ koji je uparen sa školom $j u$ algoritmu. Ukoliko postoji opravdana zavist, uparivanje nije stabilno. U prethodnom 
primeru, učenik 3 preferira školu 1 u koju je upisan učenik 1, a istovremeno učenik 3 ima veći prioritet u školi 1 od učenika 1 . S druge strane, alokacija u algoritmu najviših ciklusa trgovanja je efikasnija od one koja se ostvaruje $\mathrm{u}$ algoritmu odloženog prihvatanja, jer su učenici 1 i 4 upareni sa školama koje imaju veći rang na listi njihovih preferencija, dok su učenici 2 i 3 indiferentni između dve alokacije.

\section{OSOBINE ALGORITAMA UPARIVANJA}

U prethodnom primeru pošli smo od pretpostavke da će učenici u svakom algoritmu istinito iskazati svoje preferencije. Međutim, problem sa bostonskim algoritmom je u tome što učenici imaju podsticaj da iskazuju preferencije koje ne odgovaraju stvarnim preferencijama, i učenik kao najbolji izbor navodi školu za koju pretpostavlja da ima najveću mogućnost da bude upisan, a koja se, možda, ne nalazi u vrhu liste njegovih preferencija. To znači da u bostonskom mehanizmu određujemo Nešovu ravnotežu.

U sledećem primeru, imamo dva učenika i dve škole sa po jednim mestom (Tabela 12). Pretpostavimo da je isplata 2 kad je učenik upisan u preferiranu školu, a u suprotnom ima isplatu 1.

Tabela 12 Preferencije i prioriteti

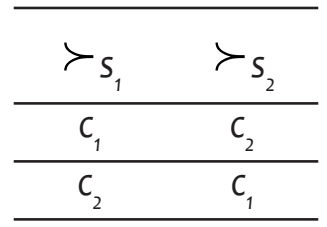

\begin{tabular}{cc}
\hline$\succ_{c_{1}}$ & $\succ_{c_{2}}$ \\
\hline$s_{2}$ & $s_{2}$ \\
\hline$s_{1}$ & $s_{1}$ \\
\hline
\end{tabular}

Izvor: Autor

Učenik ima dve strategije: da istinito navede svoje preferencije, ili da navede izmenjeni redosled stvarnih preferencija. Ova igra u normalnoj formi ima dve Nešove ravnoteže (Tabela 13).
Tabela 13 Nešove ravnoteže

\begin{tabular}{|c|c|c|c|}
\hline & & \multicolumn{2}{|c|}{ učenik 2} \\
\hline & & $c_{1}, c_{2}$ & $C_{2}, C_{1}$ \\
\hline \multirow{2}{*}{ učenik 1} & $c_{1}, c_{2}$ & 11 & \\
\hline & $c_{2}, C_{1}$ & 11 & 22 \\
\hline
\end{tabular}

Izvor: Autor

U prvoj Nešovoj ravnoteži, učenici istinito navode preferencije, a u drugoj Nešovoj ravnoteži, učenik 1 navodi izmenjen redosled preferencija. Detaljnije razmatranje Nešovih ravnoteža u Bostonskom algoritmu se može naći u P. Pathak i T. Sonmez (2008).

Prethodna igra predstavlja statičku igru sa savršenim informacijama. Ukoliko igrači znaju samo raspodelu verovatnoće za moguće tipove drugih igrača, gde tip igrača predstavlja redosled njegovih preferencija, a ne znaju sa sigurnošću njihove preferencije, imamo igru sa nesavršenim informacijama. H. Ergin i T. Sonmez (2006) dokazuju da u igri sa nesavršenim informacijama učenici mogu da budu u boljem položaju u bostonskom algoritmu nego u algoritmu odloženog prihvatanja.

U prethodnom razmatranju videli smo da je glavni nedostatak bostonskog algoritma to što učenici ne iskazuju istinito svoje preferencije. Međutim, bostonski algoritam poseduje i neka poželjna svojstva koja navode F. Kojima i U. Unver (2014). Prvo, ovaj algoritam striktno uvažava navedeni redosled preferencija, što znači da ako neki učenik nije uparen sa školom koju preferira u odnosu na školu sa kojom je uparen, preferirana škola je popunila mesta sa učenicima koji su naveli tu školu na višem mestu na listi preferencija. Druga poželjna osobina bostonskog algoritma je da povećanje broja raspoloživih mesta $u$ školama ne može da dovede učenike u lošiji položaj. Treća poželjna osobina ovog mehanizma je da ako se broj učenika koji učestvuju u uparivanju smanji, ostali učenici ne mogu da budu u lošijem položaju. Konačno, ukoliko iz procesa uparivanja uklonimo učenika koji je uparen sa određenom školom, neće doći do promene škole sa kojom su upareni ostali učenici. 
Algoritam odloženog prihvatanja dovodi do istinitog otkrivanja preferencija. Druga poželjna osobina ovog algoritma je da eliminiše opravdanu zavist, a najveći nedostatak je što alokacija koja se ostvaruje nije efikasna. Kod uparivanja jedan prema jedan, u algoritmu u kome jedna strana tržišta upućuje predlog drugoj strani, akteri koji upućuju predlog imaju podsticaj da istinito otkriju svoje preferencije. Međutim, uparivanje učenika i škola predstavlja slučaj uparivanja više prema jedan, jer škola može da bude uparena sa više učenika, dok svaki učenik može da bude uparen sa samo jednom školom. A. Roth (1985) je dokazao da u algoritmu u kome učenici upućuju predlog školi, učenici istinito iskazuju svoje preferencije. Međutim, u algoritmu u kome škole upućuju predlog učenicima, škole imaju podsticaj da netačno iskažu svoje prioritete.

Ovo možemo da ilustrujemo sledećim primerom u kome imamo 3 škole i 4 učenika, pri čemu prva škola može da upiše 2 učenika, a ostale škole po jednog učenika. Pretpostavimo da učenici i škole imaju sledeće preferencije i prioritete (Tabela 14 i Tabela 15).

Tabela 14 Prioriteti

\begin{tabular}{ccc}
\hline$\succ_{\mathrm{C}_{1}}$ & $\succ_{\mathrm{C}_{2}}$ & $\succ_{\mathrm{c}_{3}}$ \\
\hline$s_{1}$ & $\mathrm{~s}_{1}$ & $\mathrm{~s}_{3}$ \\
\hline$s_{2}$ & $\mathrm{~s}_{2}$ & $\mathrm{~s}_{1}$ \\
\hline$s_{3}$ & $\mathrm{~s}_{3}$ & $\mathrm{~s}_{2}$ \\
\hline$s_{4}$ & $s_{4}$ & $s_{4}$ \\
\hline$q_{1}=2$ & $q_{2}=1$ & $q_{3}=1$ \\
\hline
\end{tabular}

Izvor: Roth, 1985

Tabela 15 Preferencije

\begin{tabular}{cccc}
\hline$\tau_{s_{1}}$ & $\succ_{S_{2}}$ & $\succ_{s_{3}}$ & $\succ_{s_{4}}$ \\
\hline$c_{3}$ & $c_{2}$ & $c_{1}$ & $c_{1}$ \\
\hline$c_{1}$ & $c_{1}$ & $c_{3}$ & $c_{2}$ \\
\hline$c_{2}$ & $c_{3}$ & $c_{2}$ & $c_{3}$ \\
\hline
\end{tabular}

Izvor: Roth, 1985
Prvo pretpostavimo da škole istinito saopštavaju svoje prioritete. U tom slučaju primenom algoritma odloženog prihvatanja u kome škole upućuju predlog dobijamo uparivanje: $\mu^{C}=\left[\left(c_{1^{\prime}}\left(s_{3^{\prime}}, s_{4}\right)\right),\left(c_{2^{\prime}}, s_{2}\right)\left(c_{3^{\prime}}, s_{1}\right)\right]$. Međutim, školi 1 se isplati da navede drugačije prioritete od stvarnih. Pretpostavimo da škola 1 izostavi učenike 1 i 3 sa liste svojih prioriteta, i navede

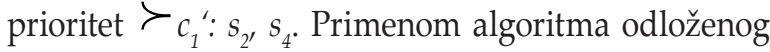
prihvatanja, u kome škola upućuje predlog, dobijamo uparivanje: $\mu^{C^{\prime}}=\left[\left(c_{1^{\prime}}\left(s_{2}, s_{4}\right)\right),\left(c_{2^{\prime}} s_{1}\right)\left(c_{3^{\prime}} s_{3}\right)\right]$. Vidimo da se školi 1 isplati ova strategija, jer je uparena sa učenicima 2 i 4, dok, kad istinito navede svoje prioritete uparena je sa učenicima 3 i 4 .

Pored manipulacije prioritetima, škole mogu da manipulišu kapacitetima da bi bile uparene sa skupom preferiranih učenika. Škola ne može da navede da ima veći kapacitet od stvarnog, ali može da navede da ima manji kapacitet. Ovaj problem detaljno je analizirao T. Sonmez (1997).

Razmotrimo primer $\mathrm{u}$ kome imamo tri učenika i dve škole, pri čemu prva škola može da primi dva učenika, a druga škola može da primi jednog učenika. Preferencije i prioriteti su prikazani u Tabeli 16 i Tabeli 17.

Tabela 16 Prioriteti

\begin{tabular}{cc}
\hline$\tau_{c_{1}}$ & $\succ_{c_{2}}$ \\
\hline$s_{1}$ & $s_{3}$ \\
\hline$s_{2,} s_{3}$ & $s_{1}$ \\
\hline$s_{2}$ & $s_{2}$ \\
\hline$s_{3}$ & \\
\hline$q_{1}=2$ & $q_{2}=1$ \\
\hline
\end{tabular}

Izvor: Autor

Tabela 17 Preferencije

\begin{tabular}{ccc}
\hline$\succ_{\mathrm{S}_{1}}$ & $\succ_{\mathrm{S}_{2}}$ & $\succ_{\mathrm{S}_{3}}$ \\
\hline $\mathrm{c}_{2}$ & $\mathrm{c}_{1}$ & $\mathrm{c}_{1}$ \\
\hline $\mathrm{c}_{1}$ & $\mathrm{c}_{2}$ & $\mathrm{c}_{2}$ \\
\hline
\end{tabular}

Izvor: Autor 
Ukoliko obe škole navedu istinite kapacitete, algoritam odloženog prihvatanja u kome učenici upućuju predlog dovodi do uparivanja: $\mu^{S}\left(q_{1}=2, q_{2}=1\right)=\left(\left(c_{1^{\prime}}\left(s_{2^{\prime}} s_{3}\right)\right),\left(c_{2^{\prime}} s_{1}\right)\right)$.

Pretpostavimo da škola 1 navede da ima manji kapacitet i da može da primi samo jednog učenika. Nakon ove manipulacije, algoritam odloženog prihvatanja dovodi do alokacije: $\mu^{S}\left(q_{1}=1, q_{2}=1\right)=$ $\left(\left(c_{1}, s_{1}\right),\left(c_{2}, s_{3}\right)\right)$. Vidimo da se školi 1 isplati ovakva manipulacija jer je uparena sa učenikom 1 koga preferira $\mathrm{u}$ odnosu na to da bude uparena sa učenicima 2 i 3. Pomalo paradoksalno, i škola 2 je u boljem položaju usled manipulacije kapacitetima škole 1, jer je sad uparena sa učenikom 3 koga preferira u odnosu na učenika 1.

Videli smo da škole imaju podsticaj da neistinito iskazuju svoje prioritete, ili da prijavljuju manji kapacitet od onog koji stvarno imaju. Međutim, F. Kojima i P. Pathak (2009) dokazuju da podsticaj za ove dve vrste manipulacija na velikim tržištima teži nuli.

Što se tiče algoritma najviših ciklusa trgovanja, ovaj algoritam dovodi do istinitog otkrivanja preferencija i do efikasne alokacije. Najveći nedostatak ovog algoritma je što ne eliminiše opravdanu zavist. Detaljnije poređenje karakteristika ova dva algoritma može se naći u radovima: (Abdulkardiroglu \& Sonmez, 2003; Abdulkardiroglu, 2013).

Videli smo da algoritam odloženog prihvatanja dovodi do gubitka efikasnosti u odnosu na algoritam najviših ciklusa trgovanja. Polazeći od ove ideje, O. Kesten (2010) razmatra da li je moguće poboljšati efikasnost algoritma odloženog prihvatanja tako što bi bila izvršena izmena redosleda škola na osnovu preferencija učenika. Ako se vratimo na naš početni primer, u prvom koraku algoritma odloženog prihvatanja, učenik 3 se prijavljuje u školu 1, ali mu ovo ne donosi nikakvu korist, jer je u kasnijim koracima algoritma odbijen u ovoj školi, dok je za učenika 1 koji je odbijen u prvom koraku škola 1 najbolji izbor. Dakle, učenik 3 stvara negativne eksternalije učeniku 1 bez ikakve koristi za sebe. Upravo u ovome O. Kesten (2010) vidi mogućnost za poboljšanje efikasnosti algoritma odloženog prihvatanja, tako što bi sa liste preferencija učenika koji stvara negativne eksternalije bez koristi za sebe bile izbrisane kritične škole.

Za primenu ovog algoritma potrebno je da učenik koji narušava uparivanje ostalih bez ikakve koristi za sebe prihvati eliminisanje kritične škole sa liste njegovih preferencija. Algoritam koji funkcioniše na ovaj način naziva se mehanizam odloženog prihvatanja koji je prilagođen za efikasnost, i ova procedura treba da eliminiše gubitak efikasnosti koji nastaje iz prethodno opisanog razloga. Očigledno je da ovaj modifikovani algoritam dominira u Paretovom smislu nad standardnim algoritmom odloženog prihvatanja. Ukoliko svi učenici koji stvaraju negativne eksternalije pristanu na eliminisanje kritične škole iz liste preferencija, modifikovani algoritam dovodi do efikasne alokacije.

$\mathrm{U}$ prethodnom primeru bi trebalo da sa liste preferencija učenika 3 izostavimo školu 1, i primenimo algoritam odloženog prihvatanja. Međutim, nakon ove izmene, videli bismo da učenik 3 ponovo stvara negativne eksternalije drugim učenicima bez ikakve koristi za sebe prijavljivanjem u školu 2, jer će $u$ narednim koracima algoritma biti odbijen i u ovoj školi. Dakle, neophodno je da sa liste preferencija učenika 3 eliminišemo školu 1 i školu 2. Nakon ovih izmena prikazanih u Tabeli 18 i Tabeli 19 možemo da primenimo modifikovani algoritam odloženog prihvatanja.

Tabela 18 Prioriteti

\begin{tabular}{cccc}
\hline$\succ_{c_{1}}$ & $\succ_{c_{2}}$ & $\succ_{c_{3}}$ & $\succ_{c_{4}}$ \\
\hline$s_{4}$ & $s_{1}$ & $s_{4}$ & $s_{2}$ \\
\hline$s_{2}$ & $s_{2}$ & $s_{3}$ & $s_{3}$ \\
\hline$s_{3}$ & $s_{3}$ & $s_{2}$ & $s_{1}$ \\
\hline$s_{1}$ & $s_{4}$ & $s_{1}$ & $s_{4}$ \\
\hline
\end{tabular}

Izvor: Autor 
Tabela 19 Preferencije

\begin{tabular}{cccc}
\hline$\tau_{s_{1}}$ & $\succ_{s_{2}}$ & $\succ_{s_{3}}$ & $\succ_{s_{4}}$ \\
\hline$c_{1}$ & $c_{4}$ & & $c_{4}$ \\
\hline$c_{2}$ & $c_{3}$ & & $c_{2}$ \\
\hline$c_{3}$ & $c_{2}$ & $c_{4}$ & $c_{1}$ \\
\hline$c_{4}$ & $c_{1}$ & $c_{3}$ & $c_{3}$ \\
\hline
\end{tabular}

Izvor: Autor

Uz ove izmene $u$ prvom koraku algoritma imamo sledeću situaciju (Tabela 20).

Tabela 20 Povećanje efikasnosti (1)

\begin{tabular}{cccc}
\hline$c_{1}$ & $c_{2}$ & $c_{3}$ & $c_{4}$ \\
\hline$s_{1}$ & & & $s_{2}, s_{3}, s_{4}$ \\
\hline
\end{tabular}

Izvor: Autor

Učenici 3 i 4 su odbijeni u školi 4 , i prijavljuju se u škole 3 i 2, u drugom koraku (Tabela 21).

Tabela 21 Povećanje efikasnosti (2)

\begin{tabular}{llll}
\hline$c_{1}$ & $C_{2}$ & $c_{3}$ & $C_{4}$ \\
\hline$S_{1}$ & $S_{4}$ & $S_{3}$ & $S_{2}$ \\
\hline
\end{tabular}

Izvor: Autor

Alokacija koju smo dobili odgovara alokaciji koja se ostvaruje $\mathrm{u}$ algoritmu najviših ciklusa trgovanja. Prema tome, modifikovani algoritam odloženog prihvatanja nas je doveo do alokacije koja je efikasna u Paretovom smislu.
POVEĆANJE RANGIRANJA ŠKOLE

NA LISTI PREFERENCIJA USLED POBOLJŠANJA NJENOG KVALITETA I MANJINSKI UČENICI

Algoritam odloženog prihvatanja možemo da analiziramo sa aspekta komparativne statike, tj. kako se menja uparivanje usled toga što neka škola poboljša svoj kvalitet. Usled poboljšanja kvaliteta škole, učenici bi trebalo da povećaju rang koji toj školi dodeljuju na listi preferencija. Algoritam odloženog prihvatanja uvažava poboljšanje kvaliteta škole ukoliko je škola, uparena sa učenikom koji ima veći prioritet nakon što škola poveća svoj kvalitet.

Razmotrimo početni primer i pretpostavimo da škola 3 poboljšava svoj kvalitet i da učenik 3 stavlja školu 3 na vrh liste svojih preferencija (Tabela 22 i Tabela 23).

Tabela 22 Prioriteti

\begin{tabular}{cccc}
\hline$\succ_{c_{1}}$ & $\succ_{c_{2}}$ & $\succ_{c_{3}}$ & $\succ_{c_{4}}$ \\
\hline$s_{4}$ & $s_{1}$ & $s_{4}$ & $s_{2}$ \\
\hline$s_{2}$ & $s_{2}$ & $s_{3}$ & $s_{3}$ \\
\hline$s_{3}$ & $s_{3}$ & $s_{2}$ & $s_{1}$ \\
\hline$s_{1}$ & $s_{4}$ & $s_{1}$ & $s_{4}$ \\
\hline
\end{tabular}

Izvor: Autor

Tabela 23 Preferencije

\begin{tabular}{cccc}
\hline$\succ_{\mathrm{S}_{1}}$ & $\succ_{\mathrm{S}_{2}}$ & $\succ_{\mathrm{s}_{3}}$ & $\succ_{\mathrm{S}_{4}}$ \\
\hline$c_{1}$ & $c_{4}$ & $c_{3}$ & $c_{3}$ \\
\hline$c_{2}$ & $c_{3}$ & $c_{1}$ & $c_{4}$ \\
\hline$c_{3}$ & $c_{2}$ & $c_{2}$ & $c_{2}$ \\
\hline$c_{4}$ & $c_{1}$ & $c_{4}$ & $c_{1}$ \\
\hline
\end{tabular}

Izvor: Autor 
Nakon ove izmene i primene algoritma odloženog prihvatanja, dobijamo sledeće uparivanje (Tabela 24).

Tabela 24 Povećanje kvaliteta škole

\begin{tabular}{cccc}
\hline$C_{1}$ & $C_{2}$ & $C_{3}$ & $C_{4}$ \\
\hline$S_{3}$ & $S_{1}$ & $S_{4}$ & $S_{2}$ \\
\hline
\end{tabular}

Izvor: Autor

U primeru vidimo da je uvaženo poboljšanje kvaliteta škole 3 koja je sada uparena sa učenikom 4 umesto sa učenikom 3. Međutim, lako je konstruisati primer u kome algoritam odloženog prihvatanja ne uvažava poboljšanje kvaliteta škole. Pored toga, J. W. Hatfield, F. Kojima i Y. Narita (2017) dokazuju da ni bostonski ni algoritam najviših ciklusa trgovanja ne uvažavaju uvek poboljšanje kvaliteta škole.

Analizirajući ovaj problem komparativne statike na velikim tržištima, J. W. Hatfield, F. Kojima i Y. Narita (2017) dokazuju da algoritam odloženog prihvatanja uvažava poboljšanje kvaliteta škole na velikim tržištima. Drugim rečima, nakon poboljšanja kvaliteta škole, kako se veličina tržišta povećava, verovatnoća da škola bude uparena sa učenikom kome dodeljuje manji prioritet se smanjuje. Međutim, bostonski i algoritam najviših ciklusa trgovanja nemaju ovo svojstvo na velikim tržištima. Prema tome, algoritam odloženog prihvatanja pruža podsticaj školama da poboljšaju svoj kvalitet, dok bostonski, i algoritam najviših ciklusa trgovanja nemaju ovo svojstvo.

Učenici se razlikuju prema materijalnom stanju, društvenoj grupi, rasnoj pripadnosti, itd. Škole koje su popularne nalaze se u centralnim delovima grada gde žive učenici koji su boljeg imovinskog stanja. Pošto škole određuju prioritet na osnovu udaljenosti mesta stanovanja učenika od škole, učenici koji su lošijeg imovinskog stanja nemaju veliku mogućnost da budu upisani u popularne škole. $U$ tom cilju, uvode se kvote za manjinske učenike $u$ popularnim školama. U najvećem broju slučajeva, ovakva politika dovodi manjinske učenike u bolji položaj. Međutim, F. Kojima (2012) dokazuje da ove kvote mogu u određenim slučajevima da dovedu manjinske učenike u lošiji položaj, pošto se većinski učenici prijavljuju u druge popularne škole u kojima nema kvote i time smanjuju mogućnost manjinskim učenicima da budu upisani.

Sledeći primer ilustruje situaciju kad uvođenje kvote dovodi manjinske učenike $u$ lošiji položaj. U ovom primeru imamo 3 učenika i 2 škole, od kojih prva škola ima 1 mesto, a druga škola 2 mesta. Preferencije učenika i prioriteti škola su prikazani u Tabeli 25 i Tabeli 26. Učenici 1 i 2 su većinski, a učenik 3 je manjinski.

Tabela 25 Preferencije

\begin{tabular}{ccc}
\hline$\succ_{\mathrm{s}_{1}}$ & $\succ_{\mathrm{s}_{2}}$ & $\succ_{\mathrm{s}_{3}}$ \\
\hline $\mathrm{c}_{2}$ & $\mathrm{c}_{2}$ & $\mathrm{c}_{1}$ \\
\hline $\mathrm{c}_{1}$ & $\mathrm{c}_{1}$ & $\mathrm{c}_{2}$ \\
\hline
\end{tabular}

Izvor: Autor

Tabela 26 Prioriteti

\begin{tabular}{cc}
\hline$\succ_{c_{1}}$ & $\succ_{c_{2}}$ \\
\hline$s_{1}$ & $s_{3}$ \\
\hline$s_{2}$ & $s_{2}$ \\
\hline$s_{3}$ & $s_{1}$ \\
\hline$q_{1}=1$ & $q_{2}=2$ \\
\hline
\end{tabular}

Izvor: Autor

Prvo određujemo alokaciju uz pretpostavku da ne postoji kvota za manjinske učenike. U algoritmu odloženog prihvatanja u kome učenici upućuju predlog, dobijamo sledeću alokaciju (Tabela 27).

Tabela 27 Manjinski učenici (1)

\begin{tabular}{cc}
\hline$C_{1}$ & $C_{2}$ \\
\hline$S_{3}$ & $S_{1}, S_{2}$ \\
\hline
\end{tabular}

Izvor: Autor 
Pretpostavimo sada da škola 2 uvodi kvotu, tako da rezerviše jedno mesto za manjinskog učenika 3. Algoritam odloženog prihvatanja daje sledeću alokaciju (Tabela 28).

Tabela 28 Manjinski učenici (2)

\begin{tabular}{cc}
\hline$C_{1}$ & $C_{2}$ \\
\hline$S_{1}$ & $S_{2}, S_{3}$ \\
\hline
\end{tabular}

Izvor: Autor

Nakon uvođenja kvote manjinski učenik 3 je uparen sa manje preferiranom školom 2.

Pored uvođenja kvote, drugi način za favorizovanje manjinskih učenika je izmena prioriteta, tako da se manjinskim učenicima daje veći prioritet $\mathrm{u}$ odnosu na većinske učenike, a prioriteti unutar svake od ovih grupa ostaju isti. Dalje, F. Kojima (2012) dokazuje da i algoritam najviših ciklusa trgovanja može da dovede manjinske učenike u lošiji položaj ako se uvede kvota za ove učenike, ili ako se izmene prioriteti u njihovu korist.

Da bi bio umanjen problem koji se javlja kad uvođenje kvote dovodi manjinske učenike u nepovoljniji položaj, I. Hafalir, B. Yenmez i M. Yildirim (2013) predlažu da se umesto fiksnih kvota koriste fleksibilne kvote. Kad se primenjuje fiksna kvota, škola nema pravo da upiše većinske učenike u okviru kvote za manjinske, čak iako se ne prijavi dovoljan broj manjinskih učenika za popunjavanje kvote. Kod fleksibilne kvote, škola prvo upisuje manjinske učenike $\mathrm{u}$ okviru njihove kvote, ali nepopunjena mesta $\mathrm{u}$ okviru ove kvote može da popuni većinskim učenicima. Simulaciona analiza koju su izvršili ovi autori pokazuje da je broj manjinskih učenika koji su u boljem položaju u algoritmima odloženog prihvatanja i najviših ciklusa trgovanja sa fleksibilnom kvotom značajno veći od broja manjinskih učenika koji su u boljem položaju u ovim algoritmima sa fiksnom kvotom.

\section{OGRANIČENA DUŽINA LISTE PREFERENCIJA}

U prethodnom razmatranju pretpostavljali smo da učenici mogu da navedu svoje preferencije za neograničenu dužinu liste škola. U stvarnosti, učenici imaju ograničenje na dužinu liste svojih preferencija. Na primer, u Njujorku, izbor je ograničen na najviše dvanaest škola, dok je u Bostonu bilo moguće navesti najviše pet škola pre 2006. Uz ovu pretpostavku nije više izvesno da će algoritmi odloženog prihvatanja i najviših ciklusa trgovanja dovesti do istinitog otkrivanja preferencija. Drugim rečima, u ovim algoritmima, uz ograničenu dužinu liste preferencija, potrebno je da odredimo Nešovu ravnotežu, kao i u bostonskom algoritmu bez ovog ograničenja. Stoga, G. Haeringer i F. Klijn (2009) određuju Nešove ravnoteže $\mathrm{u}$ algoritmima sa ograničenom listom preferencija $\mathrm{u}$ bostonskom mehanizmu, algoritmu odloženog prihvatanja i algoritmu najviših ciklusa trgovanja. Značajan rezultat do koga dolaze ovi autori je da su u bostonskom algoritmu i algoritmu najviših ciklusa trgovanja Nešove ravnoteže nezavisne od dužine liste preferencija. S druge strane, Nešove ravnoteže u algoritmu odloženog prihvatanja imaju hijerarhijski odnos, što znači da Nešova ravnoteža u algoritmu sa kraćom listom preferencija predstavlja Nešovu ravnotežu u algoritmu sa dužom listom preferencija.

Određivanje Nešove ravnoteže $u$ algoritmu odloženog prihvatanja možemo da ilustrujemo na osnovu primera iz G. Haeringer i F. Klijn (2009). U ovom primeru imamo tri učenika i tri škole, i svaka škola može da primi jednog učenika. Dužina liste preferencija je ograničena na dve škole. U Tabeli 29 prikazane su preferencije učenika uz neograničenu dužinu liste preferencija, preferencije uz ograničeni izbor, kao i prioriteti škola.

Primenom algoritma odloženog prihvatanja u kome učenici upućuju predlog na osnovu ograničene dužine liste preferencija, dobijamo alokaciju: $\left[\left(s_{1}, c_{1}\right)\right.$, $\left.\left(s_{2}, c_{2}\right),\left(s_{3}, c_{3}\right)\right]$. U ovoj alokaciji postoji opravdana zavist, pošto učenik 2 preferira školu 3, i ima veći prioritet $u$ toj školi nego učenik 3. Ovde dolazimo do rezultata koji odstupa od ranijih zaključaka, jer alokacija koja se ostvaruje u Nešovoj ravnoteži u algoritmu odloženog 
prihvatanja ne mora da bude stabilna kad je dužina liste preferencija ograničena.

Tabela 29 Ograničena lista preferencija

\begin{tabular}{|c|c|c|c|c|c|c|c|c|}
\hline$\succ_{s}$ & $\succ_{\mathrm{s}_{2}}$ & $\succ_{s_{3}}$ & $\succ_{S_{1}}{ }^{(2}$ & $\succ_{S_{2}}$ & $\succ_{S_{3}}$ & & & \\
\hline$c_{1}$ & $c_{3}$ & $c_{3}$ & $c_{1}$ & $c_{1}$ & $c_{3}$ & $\mathrm{~S}_{3}$ & $\mathrm{~S}_{3}$ & $S_{1}$ \\
\hline$C_{2}$ & $c_{1}$ & $C_{2}$ & $c_{3}$ & $c_{2}$ & $c_{1}$ & $S_{1}$ & $S_{1}$ & $S_{2}$ \\
\hline$c_{3}$ & $C_{2}$ & $c_{1}$ & & & & $S_{2}$ & $S_{2}$ & $\mathrm{~S}_{3}$ \\
\hline
\end{tabular}

Izvor: Haeringer \& Klijn, 2009

Da bismo u algoritmu odloženog prihvatanja sa ograničenom dužinom liste preferencija dobili stabilno uparivanje, potrebno je da prioriteti škola ispunjavaju H. Ergin-ov uslov acikličnosti (2002). U algoritmu najviših ciklusa trgovanja, ne ostvaruje se stabilna alokacije čak i kad nema ograničenja na dužinu liste preferencija. Stoga je u ovom slučaju neophodno da prioriteti škola ispune strožiji uslov koji se naziva O. Kesten-ov uslov acikličnosti (2006). Ovi uslovi sadrže dva poduslova. Ciklični uslov se zasniva na tome da prioriteti škola formiraju ciklus, tako da, na primer, učenik 1 ima veći prioritet u školi 1 od učenika 3, dok u školi 2 učenik 3 ima veći prioritet od učenika 1. Ukoliko obe škole imaju iste prioritete ciklični uslov nikad nije ispunjen. Drugi poduslov je uslov retkosti koji se sastoji u tome da postoji značajan broj učenika koji konkurišu za mesta u školama. Ako svaka škola ima broj mesta koji je jednak broju učenika, uslov retkosti nikad nije ispunjen. Kako se smanjuje broj mesta u školi u odnosu na ukupan broj učenika, povećava se konkurencija za raspoloživa mesta.

Da bi alokacija koja se ostvaruje u algoritmu najviših ciklusa trgovanja bila efikasna uz ograničenu dužinu liste preferencija, potrebno je da prioriteti škola ispunjavaju uslov $X$-acikličnosti, dok je za efikasnost u algoritmu odloženog prihvatanja potreban strožiji uslov za prioritete škola koji se naziva jaka $X$-acikličnost.

\section{PROBLEM INDIFERENTNOSTI}

U dosadašnjem izlaganju polazili smo od pretpostavke da škole imaju striktne prioritete kad rangiraju učenike. Međutim, u stvarnosti učenici pripadaju prioritetnim grupama, pri čemu su škole indiferentne prema učenicima iz iste grupe, dok između različitih grupa postoji striktan prioritet. Algoritme uparivanja nije moguće primeniti u slučaju kad prioriteti nisu striktni, pa je potrebno relaciju slabog prioriteta transformisati $\mathrm{u}$ relaciju striktnog prioriteta. Jedna mogućnost za razrešenje indiferentnosti koju koriste A. Erdil i H. Ergin (2008) je da se učenicima koji imaju manji indeks $u$ okviru iste prioritetne grupe daje veći prioritet. Na primer, ako istoj grupi pripadaju učenici 1, 2 i 3, učenik 1 ima najveći prioritet, zatim, učenik 2, pa učenik 3. Ovakvo proizvoljno pravilo za razrešenje indiferentnosti ne garantuje da će alokacija koja se ostvaruje $u$ algoritmu odloženog prihvatanja biti stabilna. Stoga, A. Erdil i H. Ergin (2008) predlažu upotrebu stabilnog ciklusa poboljšanja, kako bi se od proizvoljnog uparivanja došlo do stabilnog uparivanja.

Pored prethodno navedene mogućnosti, za razrešenje indiferentnosti u izboru škole, A. Abdulkardiroglu, P. Pathak i A. Roth (2009) koriste jedinstveno i višestruko pravilo za razrešenje indiferentnosti. Kod višestrukog pravila (DA-Multiple Tie Breaking-MTB) svakom učeniku se dodeljuje poseban lutrijski broj za različite škole, dok se kod jedinstvenog pravila (DASingle Tie Breaking-STB) svakom učeniku dodeljuje isti lutrijski broj za različite škole. Moguće je dokazati da je prosečan rang škole u koju su upisani učenici viši na listi njihovih preferencija u DA-STB nego u DAMTB.

Svi navedeni načini za razrešenje indiferentnsti imaju zajedničku osobinu da učenici nemaju nikakav uticaj na generisanje stiktnih priroriteta na osnovu slabih prioriteta. Dalje usavršavanje načina za razrešenje indiferentnosti nas dovodi do algoritma odloženog prihvatanja u kome učenici imaju mogućnost da svojim izborom utiču na razrešavanje indiferentnosti. Ovaj algoritam su konstruisali A. Abdulkadiroglu, Y-K. Che i Y. Yasuda (2015), pod nazivom algoritam odloženog prihvatanja sa mogućnošću izbora (ChoiceAugmented Deferred Acceptance-CADA). 
Pojednostavljeno objašnjenje načina na koji funkcioniše ovaj algoritam možemo da prikažemo pomoću primera u kome imamo tri učenika i tri škole, pri čemu svaka škola može da upiše jednog učenika. Svi učenici pripadaju istoj prioritetnoj grupi, što znači da su škole indiferentne između njih. Učenici imaju sledeće kardinalne korisnosti za različite škole (Tabela 30).

Tabela 30 Kardinalne korisnosti i izbor škole

\begin{tabular}{cccc}
\hline & $u\left(s_{1}\right)$ & $u\left(s_{2}\right)$ & $u\left(s_{3}\right)$ \\
\hline$c_{1}$ & 4 & 4 & 3 \\
\hline$c_{2}$ & 1 & 1 & 2 \\
\hline$c_{3}$ & 0 & 0 & 0 \\
\hline
\end{tabular}

Izvor: Abdulkadiroglu, Che \& Yasuda, 2015

Prvo ćemo odrediti alokaciju u algoritmu odloženog prihvatanja u kome se indiferentnost razrešava tako što svaki učenik dobija lutrijski broj iz uniformne raspodele. Uz ovakav način generisanja striktnih prioriteta, učenik ima identičnu verovatnoću od $1 / 3$ da bude upisan u bilo koju školu, tako da svaki učenik ostvaruje očekivanu korisnost od 5/3. Međutim, u ovom slučaju, postoji mogućnost za poboljšanje u Paretovom smislu. Učenik 3 ima veći nivo korisnosti ako je upisan u školu 2 koja je njegov drugi najbolji izbor u odnosu na učenike 1 i 2, tako da je uparivanje u kome je učenik 3 sigurno upisan u školu 2, dok su učenici 1 i 2 upisani u škole 1 i 3 sa verovatnoćom $1 / 2$, superiorno $u$ Paretovom smislu $u$ odnosu na početnu situaciju kad svi učenici učestvuju u lutriji. U poslednjem slučaju, svaki učenik ima očekivanu korisnost od 2, što je viši nivo korisnosti od 5/3. Da bismo došli do ovog uparivanja, potrebno je da svakom učeniku ponudimo izbor između sigurnog upisa u školu 2 i lutrije u kojoj može da se upiše $u$ prvu i treću školu sa podjednakom verovatnoćom. Učenici 1 i 2 će izabrati lutriju, dok će učenik 3 izabrati siguran upis u školu 2.

Uparivanje koje smo prethodno opisali je moguće ostvariti primenom algoritma odloženog prihvatanja sa mogućnošću izbora. U ovom algoritmu učenici navode listu svojih preferencija kao i jednu ciljnu školu. Kod razrešenja indiferentnosti u određenoj školi prioritet imaju učenici koji su tu školu naveli kao ciljnu. Nakon ovoga, svaki učenik dobija dva lutrijska broj koja se izvlače iz uniformne raspodele. Prvi slučajni broj koji dobija učenik je ciljni lutrijski broj, a drugi je regularni lutrijski broj. Prilikom određivanja striktnih prioriteta, prvo se uzima u obzir ciljni lutrijski broj, a zatim regularni lutrijski broj. Nakon razrešenja indiferentnosti na ovaj način, primenjuje se algoritam odloženog prihvatanja.

Generisanje striktnih prioriteta na osnovu ciljnog i regularnog lutrijskog broja možemo da ilustrujemo na primeru $u$ kome imamo deset učenika $i$ dve škole. Učenici: 1, 3, 5, 7 i 9 navode školu 1 kao ciljnu, a učenici: 2, 4, 6, 8 i 10 navode školu 2 kao ciljnu. Pretpostavimo da su učenicima dodeljeni sledeći ciljni: $T(I)$, i regularni: $R(I)$, lutrijski brojevi:

$T(I): 7,1,2,8,3,4,9,5,6,10 ; \quad R(I): 7,2,4,3,5,8,9,6,10,1$.

Za učenike sa neparnim indeksom, koji su naveli školu 1 kao ciljnu, prioritet se određuje na osnovu ciljnog lutrijskog broja, tako da je prioritet ovih učenika u prvoj školi: 7, 1, 3, 9, 5. Nakon ovoga, određuje se prioritet učenika koji nisu naveli školu 1 kao ciljnu na osnovu regularnog lutrijskog broja, tako da je potpuni redosled prioriteta u prvoj školi: 7, 1, $3,9,5,2,4,8,6,10$. Drugu školu su kao ciljnu naveli učenici sa parnim indeksom, i na osnovu ciljnog lutrijskog broja prioritet ovih učenika je: 2, 8, 4, 6, 10 . Zatim se određuje prioritet ostalih učenika na osnovu regularnog lutrijskog broja, pa je ukupan prioritet $\mathrm{u}$ drugoj školi: 2, 8, 4, 6, 10, 7, 3, 5, 9, 1 .

Na osnovu simulacione analize, A. Abdulkadiroglu, Y-K. Che i Y. Yasuda (2015) dokazuju da je, u algoritmu odloženog prihvatanja sa višestrukim pravilom za razrešenje indiferentnosti, manji broj učenika upisan u školu koja je njihov najbolji izbor, u odnosu na algoritam odloženog prihvatanja sa jedinstvenim pravilom za razrešenje indiferentnosti i algoritam odloženog prihvatanja sa mogućnošću izbora. Što se tiče poređenja poslednja dva algoritma, kad se uporedi broj učenika koji su upisani u školu koja je njihov najbolji izbor, može se utvrditi da ne postoji značajna razlika između njih. Ipak, algoritam 
odloženog prihvatanja sa mogućnošću izbora ima prednost nad algoritmom odloženog prihvatanja sa jedinstvenim pravilom za razrešenje indiferentnosi kad su u pitanju učenici koji su upisani u školu koja je njihov $k$-ti najbolji izbor, jer ovi učenici ostvaruju veću korisnost u CADA algoritmu.

\section{ZAKLJUČAK}

U ovom radu smo predstavili najznačajnije rezultate uparivanja učenika i škola koristeći pojednostavljene primere, čime je ova oblast učinjena pristupačnom široj čitalačkoj publici. Videli smo da postoje i određeni ograničavajući faktori u primeni algoritama uparivanja. Pre svega, algoritam odloženog prihvatanja ne dovodi do efikasne alokacije, što je njegov najveći nedostatak. Drugi značajan ograničavajući faktor u primeni algoritama uparivanja je ograničenje dužine liste preferencija koje učenici mogu da navedu, što narušava stabilnost uparivanja. Sa praktičnog aspekta, trebalo bi omogućiti učenicima da imaju mogućnost da navedu dovoljan broj škola kako dužina liste preferencija ne bi bila ograničavajući faktor. U stvarnosti, najveći broj učenika navodi nekoliko škola koje želi da upiše, tako da se ispostavlja da ograničenje dužine liste preferencija nije toliko značajan problem u praktičnoj primeni.

U radu smo pokazali da je moguće primeniti kooperativnu teoriju igara na probleme uparivanja. Pored toga, videli smo da je moguće kreirati kompatibilno-podsticajan mehanizam u kome učenici istinito saopštavaju svoje preferencije.

Ovaj rad ima važne implikacije u pogledu dvosmernog odnosa između teorijskih modela i prakse. S jedne strane, odsustvo cenovnog mehanizma nametnulo je potrebu za kreiranje alternativnih pravila koja bi predstavljala supstitut za tržište. S druge strane, postojeća teorijska znanja iz kooperativne teorije igara i oblikovanja ekonomskog mehanizma omogućila su da ovaj cilj bude ostvaren i da se nađe rešenje za problem koji se pojavio.

Algoritmi uparivanja su se pokazali kao vrlo uspešni za određivanje optimalne alokacije u situacijama kad tržišni mehanizam nije moguće primeniti iz zakonskih ili etičkih razloga. Pored primene na uparivanje učenika i škola, algoritmi su vrlo uspešno primenjeni na uparivanje lekara koji stažiraju i bolnica, uparivanje donora organa i pacijenata, alociranje parking mesta ili kancelarija na korisnike, itd. Pored uparivanja učenika i škola, posebno je značajna primena u uparivanju donora organa i pacijenata gde je značajno umanjen problem nekompatibilnosti.

Uparivanje učenika i škola je od velikog značaja u Republici Srbiji, s obzirom na to da se još uvek primenjuje algoritam trenutnog uparivanja, pa ovaj rad ukazuje na poboljšanja koja bi se mogla ostvariti primenom algoritma odloženog prihvatanja.

Stoga bi za buduće istraživanje bilo interesantno proveriti koliki porast blagostanja učenika bi mogao da bude ostvaren da je umesto algoritma trenutnog uparivanja korišćen algoritam odloženog prihvatanja. Ipak, ograničavajući faktor u ovoj analizi zasnovanoj na istorijskim podacima je što je moguće koristiti samo informacije o navedenim preferencijama, a poznato je da algoritam trenutnog uparivanja ne dovodi do istinitog otkrivanja preferencija. Dakle, na osnovu istorijskih podataka bi bilo moguće utvrditi porast blagostanja za navedene preferencije, tj. porast blagostanja uz navedeno ograničenje.

\section{REFERENCE}

Abdulkadiroğlu, A. (2013). School choice. In N. Vulkan, A. E. Roth \& Z. Neeman (Eds.), The Handbook of Market Design (pp. 138-169). Oxford, UK: Oxford University Press.

Abdulkadiroğlu, A., Che, Y-K., \& Yasuda, Y. (2015). Expanding "choice" in school choice. American Economic Journal: Microeconomics, 7(1), 1-42. doi: 10.1257/mic.20120027

Abdulkardiroğlu, A., \& Sönmez, T. (2003). Social choice: A mechanism design approach. American Economic Review, 93(3), 729-747. doi: 10.1257/000282803322157061

Abdulkardiroğlu, A., Pathak, P., \& Roth, A. (2005a). The New York city high school match. American Economic Review, 95(2), 364-367. doi: 10.1257/000282805774670167 
Abdulkardiroğlu, A., Pathak, P., Roth A., \& Sönmez, T. (2005b). The Boston public school match. American Economic Review, 95(2), 368-371. doi: 10.1257/000282805774669637

Abdulkardiroğlu, A., Pathak, P., \& Roth, A. (2009). Strategyproofness versus efficiency in school choice with indifferences: Redesigning the NYC school match. American Economic Review, 99(5), 1954-1978. doi: 10.1257/aer.99.5.1954

Backović, M. i Popović, Z. (2012). Matematičko modeliranje i optimizacija. Beograd, Republika Srbija: Ekonomski fakultet Univerziteta u Beogradu.

Backović, M., Popović, Z., \& Stamenković, M. (2016). Reflexive game theory approach to mutual insurance problem. Montenegrin Journal of Economics, 12(3), 87-100. doi: $10.14254 / 1800-5845.2016 / 12-3 / 6$

Erdil, A., \& Ergin, H. (2008). What's the matter with tiebreaking? Improving efficiency in school choice. American Economic Review, 98(3), 669-689. doi: 10.1257/aer.98.3.669

Ergin, H., \& Sönmez, T. (2006). Games of school choice under Boston mechanism. Journal of Public Economics, 90(1-2), 215237. doi:10.1016/j.jpubeco.2005.02.002

Ergin, H. (2002). Efficient resource allocation on the basis of priorities. Econometrica, 70(6), 2489-2497. doi: 10.1111/j.14680262.2002.00447.x

Gale, D., \& Shapely, L. (1962). College admission and the stability of marriage. American Mathematical Monthly, 69(1), 9-15.

Gale, D., \& Scarf, H. (1974). On cores and indivisibility. Journal of Mathematical Economics, 1, 23-37.

Haeringer, G., \& Klijn, F. (2009). Constrained school choice. Journal of Economic Theory, 144(5), 1921-1947. doi.org/10.1016/j. jet.2009.05.002
Hafalir, I., Yenmez B., \& Yildirim, M. (2013). Effective Affirmative Action in School Choice. Theoretical Economics 8(2), 325-363. doi: 10.3982/te1135

Hatfield, J. W., Kojima, F., \& Narita, Y. (2017). Promoting school competition through school choice: A market design approach. Journal of Economic Theory. (Forthcoming)

Kesten, O. (2006). On two competing mechanisms for priority based allocation problems. Journal of Economic Theory, 127, 155-171. doi: 10.1016/j.jet.2004.11.001

Kesten, O. (2010). School choice with consent. Quarterly Journal of Economics, 125(3), 1297-1348. doi: https://doi.org/10.1162/ qjec.2010.125.3.1297

Kojima, F. (2012). School choice: Impossibilities for affirmative action. Games and Economic Behavior, 75(2), 685-693. doi. org/10.1016/j.geb.2012.03.003

Kojima, F., \& Pathak, P. (2009). Incentives and stability in large two-sided matching markets. American Economic Review, 99(3), 608-627. doi: 10.1257/aer.99.3.608

Kojima, F., \& Ünver, U. (2014). The "Boston" school-choice mechanism: An axiomatic approach. Economic Theory, 55(3), 515-544. doi:10.1007/s00199-013-0769-8

Pathak, P., \& Sönmez, T. (2008). Leveling the playing field: Sincere and sophisticated players in the the Boston mechanism. American Economic Review, 98(4), 1636-1652. doi: 10.1257/aer.98.4.1636

Roth, A. (1985). The college admission problem is not equivalent to the marriage problem. Journal of Economic Theory, 36(2), 277-288. doi: 10.1016/0022-0531(85)90106-1

Roth, A. (2015). Who Gets What - And Why. New York, NY: Houghton Mifflin Harcourt Publishing Company.

Sönmez, T. (1997). Manipulation via capacities in two-sided matching markets. Journal of Economic Theory, 77(1), 197-204. doi.org/10.1006/jeth.1997.2316

Primljeno 18. aprila 2017, nakon revizije, prihvaćeno za publikovanje 23. avgusta 2017. Elektronska verzija objavljena 25. avgusta 2017. 
Dejan Trifunović je vanredni profesor na Ekonomskom fakultetu Univerziteta u Beogradu. Izvodi nastavu na nastavnim predmetima Teorija cena, Industrijska organizacija i Mikroekonomija. Oblast naučnog interesovanja je vezana za teoriju igara, aukcije, uparivanje, asimetrične informacije i mrežne eksternalije.

\title{
MATCHING STUDENTS TO SCHOOLS
}

\author{
Dejan Trifunovic \\ Faculty of Economics, University of Belgrade, Belgrade, The Republic of Serbia
}

In this paper, we present the problem of matching students to schools by using different matching mechanisms. This market is specific since public schools are free and the price mechanism cannot be used to determine the optimal allocation of children in schools. Therefore, it is necessary to use different matching algorithms that mimic the market mechanism and enable us to determine the core of the cooperative game. In this paper, we will determine that it is possible to apply cooperative game theory in matching problems. This review paper is based on illustrative examples aiming to compare matching algorithms in terms of the incentive compatibility, stability and efficiency of the matching. In this paper we will present some specific problems that may occur in matching, such as improving the quality of schools, favoring minority students, the limited length of the list of preferences and generating strict priorities from weak priorities.

Keywords: matching, Boston algorithm, deferred acceptance algorithm, top trading cycles

JEL Classification: C78 